\title{
Notes on Detecting The Effects of Non Tariff Measures
}

\author{
Céline Carrère \\ CERDI and University of Geneva \\ Jaime de Melo \\ University of Geneva and FERDI
}

\begin{abstract}
Alternative approaches to estimating the effects of nontariff measures (NTMs) on trade flows are discussed and evaluated critically. Recent econometric studies point to three results: (i) NTM restrictiveness measures based on an aggregate of 'core' NTMs are more restrictive than existing tariffs and, because of export composition towards agricultural products, in the aggregate, these 'core' NTMs limit market access most for low-income countries; (ii) Proxies for individual NTMs have a negative effect on the volume of bilateral trade for the detailed product under scrutiny; (iii) harmonization of standards is trade enhancing. Case studies confirm several of these patterns, and also that perceived severity of NTMs varies across products and across destinations for a given product. Across broadly defined imports at the section level, NTMs are more restrictive than the corresponding tariffs with two-thirds of the ad-valorem equivalent estimates in the 25\%-50\% range. Technical regulations and non-automatic licensing are the most used single-NTM measures and the restrictiveness of technical regulations increases with income per capita.
\end{abstract}

\footnotetext{
*Corresponding address: Céline Carrère; CERDI and University of Geneva, celine.carrere@ unige.ch / Jaime de Melo; University of Geneva and FERDI. jaime.demelo@unige.ch. CERDI (Centre d'Etudes et de Recherches sur le Développement International) FERDI (Fondation pour les Etudes et Recherches sur le Développement International) (C2011-Center for Economic Integration, Sejong Institution, Sejong University, All Rights Reserved.
} 
- JEL Classification: F1, F13, O24, O5

- Keywords: NTBs, NTMs, Trade Restriction.

\section{Introduction}

In the field of growth, the lack of robustness of cross-section studies is now well-documented. This lack of robustness has contributed to the newer diagnosticoriented approach to policy reform which is suspicious of 'best-practices' where expectations are based on the traditional presumptive approach to reforms ('we know how markets work and here is the list of reforms to be carried out'). ${ }^{1}$ This diagnosis in the field of the determinants of growth carries over to international trade policy and to the effects of Non-tariff Measures (NTMs ${ }^{2}$ ) on international trade. Whereas, until recently, NTMs were mostly dominated by quantitative restrictions or voluntary export restrictions, both of which were almost always welfare-reducing and hence 'actionable', with the proliferation of NTMs, this clear-cut diagnosis no longer holds. As a result, it is recognized that detecting the effects of NTMs in view of taking policy measures to eliminate those that are purely protectionist (in the sense of welfare-reducing) is difficult. The diagnosis is complicated by the fact that the effect of NTMs on the volume of trade (and on welfare) is also likely to depend on other behind-the-border (BTB) barriers to trade, themselves difficult to measure and to discern from NTMs (an NTM measure can be amplified if it is on a product also facing a significant BTB measure).

This paper reviews the methodologies used to detect the effects of NTMs on imports and offers (partial) new evidence, concentrating on measuring tariff equivalent effects which serve as a (partial) basis for any subsequent welfare analysis. Issues related to the welfare effects and to policy implications are taken up in our companion note. Section II reviews critically the different modeling approaches to measuring the effects of NTMs. Section III reports the results from the growing number of studies relying on the models reviewed in section II. These

'The huge success of this agnostic approach is exemplified in the recent outburst of randomize control trials for the evaluation of projects and of aid programs. Unfortunately randomized control trials cannot be applied to evaluate the impact of trade policy reforms for lack of natural control groups.

${ }^{2}$ Some make a distinction between a Non-Tariff Measure (NTM) and Non-Tariff Barrier (NTB) reserving the use of NTBs as a measure of protection. Previously most NTMs were quantitative restrictions which explains why the word NTB was often used to encompass all non-tariff measures. It may therefore be preferable to use NTM instead of NTB to underline that the measure may not be necessarily welfarereducing, but we follow tradition and will, at times use NTB. 
studies draw on the global UNCTAD NTM data base of 2002-04, but also on the rapidly growing data bases on various trade facilitation measures used to measure the importance of BTB. Section IV completes the paper with additional exploratory tabulations across products and across NTMs.

\section{Model-based Approaches to Detecting the Effects of NTMs}

The systematic analysis of the effects of NTMs has focused on evaluating their ad-valorem equivalents (i.e. on tariffs that would reduce imports by the same amount as the NTM in question) and on their effects on the volume of trade. Two modeling approaches have been used in the literature. One draws estimates using the gravity model of trade, often focusing on the effects of NTBs on the volume of aggregate bilateral trade. The other, draws on the factor-endowment-based theories of trade focusing on the volume of trade at the product level where import volumes are correlated with factor endowments, country characteristics, tariffs and various proxies of NTBs. We review briefly each approach.

\section{A. The Gravity Approach to NTM measurement}

We start with the ubiquitous gravity model, most often used to examine the effects of NTBs. While many applications stick to the gravity equation for the volume of aggregate trade, the interest here is on a comparison of NTM measures at the product level so we formulate directly the disaggregated version (see e.g. Anderson and Van Wincoop, 2004 or Feenstra, 2004). Then, the volume of bilateral trade for good $\mathrm{k}$ between $\mathrm{i}$ and $\mathrm{j}$ is given by:

$$
\ln X_{i j}^{k}=a_{i}+b_{j}-(1-\sigma) \ln t_{i j}^{k}+\varepsilon_{i j}
$$

where $X^{k}{ }_{i j}$ represents the export flows of good $k$ from country $i$ to importer $j$ (valued at cif prices), $t_{i j}^{k}$ represents all (gross) bilateral "trade costs", $\sigma$ the elasticity of substitution for good-class $k, a_{i}$ and $b_{j}$ are country (exporter and importer) fixed effects that capture all characteristics that are specific to each pair (GDPs, population, etc...) and $\varepsilon_{i j}$ is a normally distributed error term. The associated trade costs function for good $k$ between $i$ and $j, t_{i j}$, is expressed as:

$$
\ln t_{i j}^{k}=\ln \left(1+T_{i j}^{k}\right)+\gamma \ln N T M_{i j}^{k}+\delta \operatorname{In} D_{i j}+\sum \theta_{n} D U M_{i j}^{n}+v_{i j}
$$


i.e. trade costs are stipulated to be a function of the tariff rate on product $k$ imported by country $j$ from $i, T^{k}{ }_{i j}$, and of an average $N T M$ index of importer $j$ against exporter $i, N T M^{k}$; , the bilateral distance between the economic center of countries i and $j, D_{i j}$, and a set of control variables (usually dummy variables having the value of 1 if countries $i$ and $j$ share a common land border, an economic integration agreement, are on the same continent, or share the same primary language). ${ }^{3}$

Substituting (2) into (1) yields the model used to predict the effects of NTMs on the volume of bilateral trade. The problems start here. First, the gravity model works better for aggregate trade than for trade at the product-line level. This is important since we are mostly interested in the relative importance of various NTMs by sector of activity or, even better, at the product-level. Such estimates then need to be carried out at the product level where NTMs they differ across categories of products. For example, a technical regulation will imposed on chemical products but not on textiles. This is why the model must be specified at the disaggregated product level.

Second, for a given indicator, $N T M^{k}{ }_{i j}$, there is little variation in the data across suppliers to country $j$ for a given product since when an importer specifies an NTM on a product, it is usually the same for all exporters. Thus there is (even) less bilateral variation in NTMs than in tariffs and this makes identification of the effects of NTMs much more difficult. With very little variation in bilateral tariffs, and even less in the indicator of bilateral barriers, estimates will be instable, suffering from multicollinearity.

Thus, with NTMs mostly defined multilaterally (the same barrier is applied by country $j$ on its imports whomever the exporter $i$ ) and given the limited data available on NTMs, one can only estimate an NTM restrictiveness by importing country, not bilaterally, especially when using the NTMs tabulated from the WITS data base. ${ }^{4}$ Going a step further, since the initial NTM variable is importer-specific, this dramatically complicates the interpretation of the estimated coefficient for the "bilateral" NTM variable. To take an example, drawn from Anderson et al. (2008)

\footnotetext{
${ }^{3}$ An alternative specification consists in expressing all variables in relative terms, i.e. with the imports of $j$ from $i$ relative to imports from self of country $j$. In such a formulation, the estimated equation includes "border-related costs" (or "border effect") which consist of tariffs and non-tariff barriers (see Fontagné, Mayer and Zignago, 2005 for an assessment of the NTBs contribution in the overall "border effect"). ${ }^{4}$ Even with a large survey (over 10,000 respondents) such as the one designed by ECORYS in their study of EU/US NTBs, Anderson et al. (2008) explain that due to a small response numbers in each bilateral response cell, a "higher quality measure of the degree of the perceived NTBs faced by an exporter in any representative country $i$ for export to country $j$ was obtained by averaging importer $j$ responses across all exporters".
} 
who use this framework, they state that "the coefficient for bilateral NTB variables can be interpreted as -for some given of NTBs multilaterally - the effect on a particular pairing of countries of being a member of some group $m$ ". Moreover, there are further econometric problems in the data as missing values may not reflect the absence of an NTM on that particular tariff line.

In sum, even though it has been often used (see the review of the literature below), the gravity equation is not very informative if one is interested to compare the effects of different types of NTMs on a large panel of countries at a disaggregated product level.

\section{B. The Facto-endowment-based Approach to NTM measurement}

Since one is interested in the effects of NTMs at the product level, is it natural to use as a benchmark a model that isolates the determinants of the aggregate (rather than bilateral) volume of product trade and then to add on the effects of tariffs and NTMs. This approach initiated by Leamer (1990) has been extended recently by Kee et al. (2009) to the estimation of NTMs. Drawing on an earlier study (Kee et $a l ., 2009)$ in which they estimate the elasticity of demand for imports at the HS-6 product line level), they estimate the quantity-impact of NTBs for good $k$ as:

$$
\left[\ln m_{k, i}-\varepsilon_{k, i} \ln \left(1+t_{k, i}\right)\right]=\alpha_{k}+\sum_{r} \alpha_{k}^{r} C_{i}^{r}+\beta_{k} N T B_{k, i}+\sum_{r} \beta_{k}^{r} C_{i}^{r} N T B_{k, i}+\kappa_{k, i}
$$

where

$m_{k, i}$ is the import value of good $k$ in country $i$;

$\alpha_{k}$ are tariff line dummies that capture any good-specific effect;

$t_{k, i}$ is the ad-valorem tariff on good $k$ in country $i$;

$\mathcal{E}_{k, i}$ is the import demand elasticity (obtained extraneously);

$C_{i}^{r}$ are $r$ country-specific variables (agricultural land on GDP, capital on GDP and labor on GDP for relative factor endowments and GDP for economic size, a dummy for island and the average distance to world markets for geography);

$N T B_{k, i}$ is a dummy variables indicating the presence of a NTB for line $k$ imported by $i$;

$\beta_{k, i}$ the parameter that capture the impact that the NTB imposed on good $k$ in

\footnotetext{
${ }^{5}$ Anderson et al. (2008) are interested in the effects of NTBs in a two-region world (NAFTA and European Economic area). They conclude that their estimated coefficient on the NTB dummy delivers the "surcharge faced by EU exporters to NAFTA relative to a baseline NTB that implicitly affects all exporters to $j$ alike" which is not very useful for our purpose.
} 
country $i$ has on the corresponding imports.

Equation (3) is estimated at the HS-6 tariff line level. To make NTBs comparable between them and comparable with ad-valorem tariffs, Kee et al. transform the quantity impact into an ad-valorem price-equivalent (AVE) defined as $A V E=\partial \ln p^{d} / \partial N T B$, where $p^{d}$ is the domestic price. They show that the advalorem equivalent (AVE) of the NTB imposed on good $k$ by country $i$ is given by:

$$
A V E_{k, i}=\frac{e^{\hat{\beta}_{k, j}}-1}{\varepsilon_{k, i}}
$$

with $\hat{\beta}_{k, i}$ obtained from the estimation of (3). AVEs are then computed for each country at the HS-6 level and aggregated up to an aggregate measure.

This method has several advantages over the gravity approach. First, it delivers directly the sought-after tariff-equivalent of NTBs (see (4)). Second, suppose that one adds indices of trade facilitation as in e.g. Shepherd and Wilson (2008) to the NTB indices. Then one can compare directly the relative effects on imports of removing, tariffs, versus removing NTBs, and one can also compare the effects of removing the aggregate of NTBs and tariffs versus removing BTB measures. Third, insofar as the elasticity of imports is taken extraneously to the estimation, the endogeneity of imports is, at least, partly resolved.

Once one goes beyond the traditional approach relying on coverage and frequency indices, this approach is likely to be more informative than the gravitybased approach which has dominated the evaluation of the effects of NTBs (see Table 1).

The approach, however, also has several shortcomings. First, idiosyncratic measurement errors, likely to cancel out at the aggregate level, will be magnified in at the HS-6 product-line level. It is then necessary to use instrumental variable estimates as done by Kee et al. (2009). Second, it is difficult to introduce relevant control variables (beyond dummy variables) at the disaggregated level. Indeed, at the HS-6 level, there is nothing else than tariffs and trade volumes. Third, the estimate of the price elasticity of demand for imports, which is essential for computing the AVE, will likely change in magnitude with the sample period. ${ }^{6}$

\footnotetext{
${ }^{6}$ For example, textiles and clothing, subject to a large number of NTMs in the 6200 (quotas ) and 8100 (technical regulations) categories of NTBs, has witnessed a significant change since 2002-04 when the NTM data were last collected and the price elasticity of demand for imports estimated in Kee et al. (2008).
} 


\section{Econometric Estimates of the Effects of NTMs}

The extensive use of gravity equation in the assessment of specific NTMs is due to its simplicity. Since the sign of the variables that capture the effect of the NTM in the regression is not constrained, it is possible to also capture the trade-enhancing effect of regulations when they act as standards that facilitate trade. In certain cases one can also measure import elasticities with respect to variations in the restrictiveness of the standards themselves when there is some variability across countries or over time (e.g. the level of chemical residues, of aflatoxins, etc.).

Table 1 summarizes the results from some of the studies on NTMs and BTBs (when these are included in an appraisal of NTMs). As indicated by the asterisks, the overwhelming majority of studies are based on the gravity model. The table distinguishes between studies that aim at capturing the effects of NTMS on all trade flows from those that relate to specific sectors (agriculture, electronics, etc.). Three relatively robust conclusions emerge.

\section{A. NTMs are more restrictive than tariffs and low income countries face more restrictive market access conditions}

Kee et al.(2009) and Hoekman and Nicita (2008) find that NTMs generally restrict trade more than tariffs (i.e. the estimated AVEs are higher than the observed tariffs at the product line level). ${ }^{7}$ Because of the composition of trade towards agricultural products (where the aggregate of trade restrictions are estimated to be the highest), low-income countries face more restrictive market access conditions than other countries. Note however (see discussion in section II above) that the NTB restrictiveness index is an aggregate of the 5 'core' NTMs (Technical regulations, Quantity restrictions, Monopolistic measure, Prices control measures and agricultural domestic support), so that it is not possible to know which of these NTMs is the most restrictive.

\section{B. Subject to the included controls, NTMs restrict bilateral trade volumes}

The bulk of the studies in Table 1 concern product-specific trade flows. All the studies find that the particular NTM/NTB proxy used has a negative impact on the volume of bilateral trade in the product under scrutiny. While in each case, this

\footnotetext{
${ }^{7}$ This pattern would not be robust if the NTB dummy were systematically correlated positively with an omitted variable in which case the estimated AVE would be upward-biased.
} 
Table 1. Model-based estimates of NTBs

\begin{tabular}{|c|c|c|c|c|c|c|}
\hline $\begin{array}{c}\text { Authors } \\
\text { (year) }\end{array}$ & $\begin{array}{l}\text { NTB/NTM } \\
\text { studied }\end{array}$ & $\begin{array}{l}\text { NTB/NTM proxy } \\
\text { introduced in the } \\
\text { gravity equation }\end{array}$ & $\begin{array}{c}\text { NTB/NTM } \\
\text { database }\end{array}$ & $\begin{array}{l}\text { Products trade } \\
\text { flows }\end{array}$ & Sample & Main Results \\
\hline \multicolumn{7}{|c|}{ ALLTRADE FLOWS } \\
\hline $\begin{array}{l}\text { Zignago } \\
(2005)\end{array}$ & & $\begin{array}{l}\text { HS6 tariff lines subject to } \\
\text { an NTB, NTBs being } \\
\text { divided into } 4 \text { categories } c \text { / }\end{array}$ & $\begin{array}{l}\text { Thursby (2003) } \\
\text { ISIC rev2 3-digit }\end{array}$ & $\begin{array}{l}\text { in each of the } \\
\text { ISIC rev2 3-digit } \\
\text { industty }\end{array}$ & $\begin{array}{l}\text { developed } \\
\text { countries over } \\
\text { the period } \\
1976-1999\end{array}$ & $\begin{array}{l}\text { on trade flows, while the quantity NTBs show a } \\
\text { positive although insignificant coefficient. } \\
\text { Overall trade reducing effect of NTBs }=3.2 \% \text {. }\end{array}$ \\
\hline $\begin{array}{l}\text { Moenius } \\
\text { (2004)* }\end{array}$ & $\begin{array}{l}\text { International } \\
\text { and } \\
\text { Countryspe- } \\
\text { cific } \\
\text { standards }\end{array}$ & $\begin{array}{l}3 \text { Count variables: the } \\
\text { number of shared standards } \\
\text { in year } t \text {, industry } k \text { between } \\
\text { countries I and } j \text {, the number } \\
\text { of countryspecific standards } \\
\text { in the importing (exporting) } \\
\text { countries. }\end{array}$ & $\begin{array}{l}\text { PERINORM } \\
\text { database = German } \\
\text { Deutsches Intitut fur } \\
\text { Normung + Agence } \\
\text { Francaise de } \\
\text { Normalisation + Bris- } \\
\text { tish Standards Intitu- } \\
\text { tion }\end{array}$ & $\begin{array}{l}\text { Trade in } 471 \\
\text { industries }\end{array}$ & $\begin{array}{l}12(\mathrm{OECD}) \\
\text { countries } \\
\text { over } \\
1980-1995\end{array}$ & $\begin{array}{l}\text { Bilaterally shared standards are favorable to } \\
\text { bilateral trade volumes. Country-specific } \\
\text { standards of the importer reduce imports for } \\
\text { agricultural products while they increase trade } \\
\text { for manufacturing products (interpretation: } \\
\text { standards offer valuable information } \\
\text { increasing demand). }\end{array}$ \\
\hline \multicolumn{7}{|c|}{ PRODUCT-SPECIFIC TRADE FLOWS } \\
\hline $\begin{array}{l}\text { Disdier } \\
\text { and } \\
\text { Fontagné } \\
(2008)^{*}\end{array}$ & $\begin{array}{l}\text { EU } \\
\text { authorization } \\
\text { regime for } \\
\text { biotech } \\
\text { products } \\
\text { (GMOs) }\end{array}$ & $\begin{array}{l}2 \text { dummies: one equals to } 1 \\
\text { for products exported by } \mathrm{j} \\
\text { on with the EU imposes in } \mathrm{t} \text { a } \\
\text { moratorium and/or a } \\
\text { product-specific measures; } \\
\text { one equals to } 1 \text { if country } \mathrm{i} \\
\text { adopts in } \mathrm{t} \text { a national safeguard } \\
\text { measures on products exported } \\
\text { by j. }\end{array}$ & $\begin{array}{l}\text { Agbios database } \\
\text { completed with } \\
\text { scrutinity of } \\
\text { legislation. } \\
\end{array}$ & $\begin{array}{l}\text { Trade flows of } \\
\text { Maize, cotton } \\
\text { and oilseed rape } \\
\text { trade flows } \\
\text { (HS6, } 7 \text { tariff } \\
\text { lines) }\end{array}$ & $\begin{array}{l}19 \text { main } \\
\text { exporters } \\
\text { towards } 3 \\
\text { main } \\
\text { importers } \\
\text { over } \\
1994-2005\end{array}$ & $\begin{array}{l}\text { EU GMO measures reduce exports of } \\
\text { Argentina, Canada, US and Brazil for the } \\
\text { affected products, with effects varying across } \\
\text { products and complainants. Importers other } \\
\text { than the EU (New Zealand, Switzerland and } \\
\text { Norway) have also implemented measures on } \\
\text { OGMs that negatively affect their imports. }\end{array}$ \\
\hline
\end{tabular}


Table 1. Model-based estimates of NTBs (continued)

\begin{tabular}{|c|c|c|c|c|c|c|}
\hline $\begin{array}{c}\text { Authors } \\
\text { (year) }\end{array}$ & $\begin{array}{l}\text { NTB/NTM } \\
\text { studied }\end{array}$ & $\begin{array}{c}\text { NTB/NTM proxy } \\
\text { introduced in the } \\
\text { gravity equation }\end{array}$ & $\begin{array}{c}\text { NTB/NTM } \\
\text { database }\end{array}$ & $\begin{array}{l}\text { Products trade } \\
\text { flows }\end{array}$ & Sample & Main Results \\
\hline $\begin{array}{l}\text { Disdier, } \\
\text { Fontagné, } \\
\text { and } \\
\text { Mimouni } \\
(2008)^{*}\end{array}$ & $\begin{array}{l}\text { Sanitary and } \\
\text { Phyto-Sanitary } \\
\text { (SPS) mea- } \\
\text { sures and } \\
\text { Technical } \\
\text { Barriers to } \\
\text { trade (TBT) } \\
\text { on agriculture }\end{array}$ & $\begin{array}{l}3 \text { variables: a dummy equals } \\
\text { to } 1 \text { if the importing country } \\
\text { notifies at least one barrier; a } \\
\text { frequency ratio; an ad-valo- } \\
\text { rem equivalent } \\
\text { of SPS and TBT. }\end{array}$ & $\begin{array}{l}\text { UNCTAD for the } 2 \\
\text { first variables and } \\
\text { Kee, Nicita and Olar- } \\
\text { reaga (2009) } \\
\text { for the third } d /\end{array}$ & $\begin{array}{l}\text { Trade flows of } \\
\text { agricultural and } \\
\text { food industry } \\
\text { products (HS4, } \\
690 \text { tariff lines) }\end{array}$ & $\begin{array}{l}183 \text { export- } \\
\text { ers and } 154 \\
\text { importers, } \\
\text { for } 2004\end{array}$ & $\begin{array}{l}\text { SPS measures and TBTs implemented by } \\
\text { OECD countries significantly reduce their } \\
\text { imports of agricultural products from develop- } \\
\text { ing countries but do not affect trade between } \\
\text { OECD members. European imports are more } \\
\text { negatively influenced by SPS and TBTs than } \\
\text { imports of other OECD countries. }\end{array}$ \\
\hline $\begin{array}{l}\text { Otsuki, } \\
\text { Wilson } \\
\text { and } \\
\text { Sewadeh } \\
(2001 \mathrm{a})^{*}\end{array}$ & $\begin{array}{l}\text { Sanitary and } \\
\text { Phyto-Sanitary } \\
\text { (SPS) measur } \\
\text { on food: Afla- } \\
\text { toxin EU stan- } \\
\text { dards }\end{array}$ & $\begin{array}{l}1 \text { variable: the maximum } \\
\text { aflatoxin level imposed on } \\
\text { food products import by EU } \\
\text { members on countries i in } \\
1995 .\end{array}$ & $\begin{array}{l}\text { FAO survey of myc- } \\
\text { otoxin standards on } \\
\text { food and feed stuffs } \\
(1995)\end{array}$ & $\begin{array}{l}\text { Trade flows of } \\
\text { "cereals" and } \\
\text { "fruits, nuts and } \\
\text { vegetables" } \\
\text { (SITC) }\end{array}$ & $\begin{array}{l}\text { EU-15 } \\
\text { imports } \\
\text { from } 9 \text { SSA } \\
\text { countries } \\
\text { over } \\
1989-1998\end{array}$ & $\begin{array}{l}\text { A } 10 \% \text { reduction of maximum allowable level } \\
\text { of aflatoxin in European countries reduces } \\
\text { SSA exports of cereals by } 11 \% \text {, and by } 4.3 \% \\
\text { for fruits, nuts and vegetables. (Groundnuts are } \\
\text { found to be highly sensitive to aflatoxin stan- } \\
\text { dards (a 13\% reduction)). }\end{array}$ \\
\hline $\begin{array}{l}\text { Czubala, } \\
\text { Sheperd, } \\
\text { and Wil- } \\
\text { son } \\
(2009)^{*}\end{array}$ & $\begin{array}{l}\text { EU products } \\
\text { standards on } \\
\text { textile and } \\
\text { clothing }\end{array}$ & $\begin{array}{l}2 \text { Count variables: the num- } \\
\text { ber of EU standards interna- } \\
\text { tionally harmonized with the } \\
\text { ISO standards and the num- } \\
\text { ber that are not }\end{array}$ & $\begin{array}{l}\text { World Bank } \\
\text { EUSDB } \\
\boldsymbol{e} /\end{array}$ & $\begin{array}{l}\text { Trade flows of } \\
\text { clothing, fabrics } \\
\text { and fibres (HS2, } \\
14 \text { tariff lines) }\end{array}$ & $\begin{array}{l}\text { EU-15 } \\
\text { imports from } \\
47 \text { SSA } \\
\text { countries } \\
\text { over 1995- } \\
2003\end{array}$ & $\begin{array}{l}\text { Non-harmonized standards reduce Sub- } \\
\text { Saharan African exports of textile and clothing. } \\
\text { EU standards that are internationally-harmo- } \\
\text { nized to ISO standards are less trade restrict- } \\
\text { ing. }\end{array}$ \\
\hline
\end{tabular}


Table 1. Model-based estimates of NTBs

\begin{tabular}{|c|c|c|c|c|c|c|}
\hline $\begin{array}{l}\text { Authors } \\
\text { (year) }\end{array}$ & $\begin{array}{l}\text { NTB/NTM } \\
\text { studied }\end{array}$ & $\begin{array}{l}\text { NTB/NTM proxy } \\
\text { introduced in the } \\
\text { gravity equation }\end{array}$ & $\begin{array}{l}\text { NTB/NTM } \\
\text { database }\end{array}$ & $\begin{array}{l}\text { Products trade } \\
\text { flows }\end{array}$ & Sample & Main Results \\
\hline $\begin{array}{l}\text { Moenius } \\
(2006)^{*}\end{array}$ & $\begin{array}{l}\text { Product } \\
\text { standards } \\
\text { in electrical } \\
\text { goods }\end{array}$ & $\begin{array}{l}4 \text { variables: a dummy equals } \\
\text { to } 1 \text { if countries } i \text { and } j \text { have } \\
\text { exactly the same voltage }+ \\
\text { the same } 3 \text { count variables } \\
\text { than in Moenius (2004). }\end{array}$ & $\begin{array}{l}\text { Kropla (2006) for } \\
\text { electricity } \\
\text { specification and } \\
\text { PERINORM for } \\
\text { standards }\end{array}$ & $\begin{array}{l}\text { Trade in } 471 \\
\text { industries } \\
\text { sorted into } \\
\text { electricity } \\
\text { dependent } \\
\text { products or not. }\end{array}$ & $\begin{array}{l}12(\mathrm{OECD}) \\
\text { countries } \\
\text { over } \\
1980-1995\end{array}$ & $\begin{array}{l}\text { Voltage harmonization is positively associated } \\
\text { with the volume of trade in the selected indus- } \\
\text { tries. Both national and international standard- } \\
\text { ization promotes trade flows in electricity- } \\
\text { dependent products and, on average, electric- } \\
\text { ity-dependent products generally benefit more } \\
\text { from standardization than other manufactured } \\
\text { products. }\end{array}$ \\
\hline $\begin{array}{l}\text { Portugal- } \\
\text { Perez, } \\
\text { Reyes } \\
\text { and Wilson } \\
(2009)^{*}\end{array}$ & $\begin{array}{l}\text { EU product } \\
\text { standards in } \\
\text { electronics }\end{array}$ & $\begin{array}{l}2 \text { Count variables: the number } \\
\text { of EU standards } \\
\text { internationally } \\
\text { harmonized with the IEC } \\
\text { standards and the number } \\
\text { thatare not }\end{array}$ & $\begin{array}{l}\text { World Bank EU } \\
\text { Electro-technical } \\
\text { Standards } \\
\text { Database } \\
\text { (EUESDB) }\end{array}$ & $\begin{array}{l}\text { Trade in } 3 \\
\text { categories of } \\
\text { electronic and } \\
\text { related } \\
\text { products }\end{array}$ & $\begin{array}{l}\text { EU Imports } \\
\text { from } 131 \\
\text { countries } \\
\text { over } \\
1990-2006\end{array}$ & $\begin{array}{l}\text { Internationally-harmonized European stan- } \\
\text { dards expand EU imports of electronic } \\
\text { products while European standards not } \\
\text { aligned with international norms have a lower } \\
\text { effect on EU imports, in some cases a negative } \\
\text { effect (depending on the electronic product } \\
\text { considered). }\end{array}$ \\
\hline
\end{tabular}

Notes: * Estimates based on a gravity-model.

** Estimates bease on an endowment theory of trade.

$\boldsymbol{a}$ / difference between the tariff trade restrictiveness index (TTRI), capturing only tariffs, and the overall trade restrictiveness index (OTRI) including the effect of both tariff and NTMs (see Kee, Nicita and Olarreaga, 2009)

b/ available at http://econ.worldbank.org/WBSITE/EXTERNAL/EXTDEC/EXTRESEARCH/0,,contentMDK:21085342 pagePK:64214825 piPK:64214943 theSitePK: 469382,00. html c/ Haveman et al. (2003) divide NTBs into four categories: (1) Those that have direct price effects such as minimum import pricing, trigger prices, and variable levies, (2) those that involve quantity restrictions such as quotas, seasonal prohibitions, and orderly marketing arrangements, (3) those that involve quality restrictions such as health, safety or technical standards, and (4) those that involve a threat of retaliation such antidumping and countervailing duty investigations. For a given HS6 category, each NTB variable is set equal to 1 if at least one of the underlying tariff lines in that category is subject to an NTB, and 0 otherwise. Fontagne et al. (2005) aggregate this information on NTBs to match with the 3 digit ISIC rev2 classification by calculating a frequency index.

$d /$ available at http://team.univ-paris1.fr/teamperso/fontagne/data.htm

$\boldsymbol{e} /$ available at http://go.worldbank.org/6OEYNCYSD0 and http://www.wto.org/english/tratop_e/tbt_e/tbt_e.htm 
correlation may be capturing the effects of omitted variables correlated with the NTM, because all the studies (including several that have not been published) find systematically that NTMs reduce the volume of trade. For example, the studies show that the SPS and TBT measures in agriculture have a significantly negative impact on the EU imports of agricultural products.

\section{Harmonization of standards increase bilateral trade flows}

Bilaterally shared standards and harmonized standards, significantly increase trade or, at least are less trade-restricting than non-harmonized standards. This intuitively plausible result is drawn from a relatively small (but growing) number of studies and needs further verification to acquire robustness.

This said, as pointed out earlier, a major problem for virtually all the product-specific gravity studies is that the NTM variables are always importer-specific. This means that country-specific effects necessary to capture time-invariant omitted factors that influence the volume of bilateral trade cannot be included in the estimation, thereby aggravating omitted-variable bias (see discussion in section II, part B).

\section{Case Studies}

In their early influential study, Deardorff and Stern (1997) noted that "there is no substitute for NTB and sector-specific expertise. The reliability of any measure of NTBs that may be constructed for particular sectors is limited by the knowledge of the intricacies of those sectors that bear upon the measures". Case studies aim at providing this knowledge necessary to classify NTMs so as to be better informed on which ones are informative (should be kept from a welfare point of view as e.g. certain prohibitions or technical regulations for health, security or environmental reasons). We review here briefly the main results from two recent case studies (World Bank, 2008 and Mimouni et al., 2009)

The World Bank study carried out firm and governmental official interviews in thirteen countries (Cambodia, Chile, China, Indonesia, Korea, Laos, Mexico, Singapore, Thailand, Taiwan, Peru, Vietnam). The objective was to get an idea of the potential for export expansion if these countries were to face less restrictive NTMs in their main export markets. The interviews were carried out with government officials and exporter associations and/or firms in an informal manner and varied greatly across countries. For example 23 interviews were conducted in Cambodia, two with exporter associations, the rest with government officials, 
while in Mexico it was taken from a data base in Mexico's export-import Bank, while in Korea the interviews were administered to 1000 respondents that included firms and embassies.

Taken together, the thirteen case studies suggest that NTMs are particularly costly for agricultural products not only because the SPS standards vary across countries, but also because compliance costs related to certification are high as the necessary infrastructure to carry them out were found to be lacking in the countries in the sample. These costs are compounded by the cost-raising effects on perishables due to inefficient customs procedures. For manufactures, steel, chemicals, and plastics are often subject to Anti-dumping measures. Finally the interviews in the surveys indicate that arbitrariness and non-transparency plague exporters to developing countries, be it with respect to customs procedures or product standards. For exporters of these developing countries to the EU, US and Japan, the major obstacle is the complexity and level of detail in the trade procedures. Stringent Rules of Origin are often perceived as a significant barrier.

The other set of results is from a pilot study for five countries (Chile, Philippines, Thailand, Tunisia, Uganda) carried out in the context of a joint ITC-

Table 2. Non-tariff Measures experienced by exporting firms (i.e. declared as "Serious Obstacles to Trade", \%

\begin{tabular}{lcccccc}
\hline NTM group & Chile Philippines Thailand & Tunisia & $\begin{array}{c}\text { Simple } \\
\text { Uganda } \begin{array}{c}\text { cross-country } \\
\text { average }\end{array}\end{array}$ \\
\hline $\begin{array}{l}\text { Technical measures to trade } \\
\text { (e.g. product characteristic) }\end{array}$ & 70.3 & 76.4 & 93.5 & 62.7 & 64.1 & 73.4 \\
$\begin{array}{l}\text { requirement; production } \\
\text { process; conformity assessment) }\end{array}$ & & & & & & \\
$\begin{array}{l}\text { Pre-shipment inspection and } \\
\text { other customs formalities }\end{array}$ & 14.0 & 3.1 & 2.3 & 22.6 & 23.1 & 13.0 \\
$\begin{array}{l}\text { Licenses, quotes, and other } \\
\text { quantity control measures }\end{array}$ & 6.1 & 0.4 & 2.2 & 0.5 & 0.3 & 1.9 \\
$\begin{array}{l}\text { Charges, taxes and other } \\
\text { para-tariff measures }\end{array}$ & 1.2 & 2.7 & 0.2 & 4.7 & 7.4 & 3.2 \\
$\begin{array}{l}\text { Finance measures regulating } \\
\text { the access to and cost of foreig } \\
\text { exchange for imports and } \\
\text { defining the terms of payment }\end{array}$ & 2.1 & 0.6 & 0.1 & 4.2 & 0.2 & 1.4 \\
$\begin{array}{l}\text { Other } \\
\text { Total }\end{array}$ & 6.4 & 16.9 & 1.6 & 5.3 & 4.9 & 7.0 \\
\hline
\end{tabular}

Source: Mimouni et al. (2009), Table 1 in section 1.6. 
UNCTAD project aiming at obtaining a more thorough map of NTMs around the world based on a systematic update and extension of the UNCTAD-TRAINS based on the combination of official statistics (as in the current UNCTADTRAINS data base) and systematic face-to-face interviews conducted for 300-400 exporting companies (representativity at $95 \%$ confidence interval of the population of exporting companies achieved at the sector and firm level by appropriate sampling methods). These interviews were conducted in 2008, so it is interesting to see if the patterns are the same as those in the older WITS-TRAINS data base discussed below in section V. Results from the surveys in the five countries are reported in Table $2 .^{8}$

While the sample is small, beyond the expected result that technical measures are the most important form of NTM (a result also evident from the earlier datasee Table 4), several patterns emerge suggesting variation across regions of destination (perhaps due in to the product composition of exports). From Table 2, it is apparent that Thai exporters reported concerns about technical measures to trade, while Chileans faced licenses and quotas and the African countries expressed concerns about customs formalities and pre-shipment inspection.

Figure 1. Companies' Perceptions of NTMs by Destination, \%

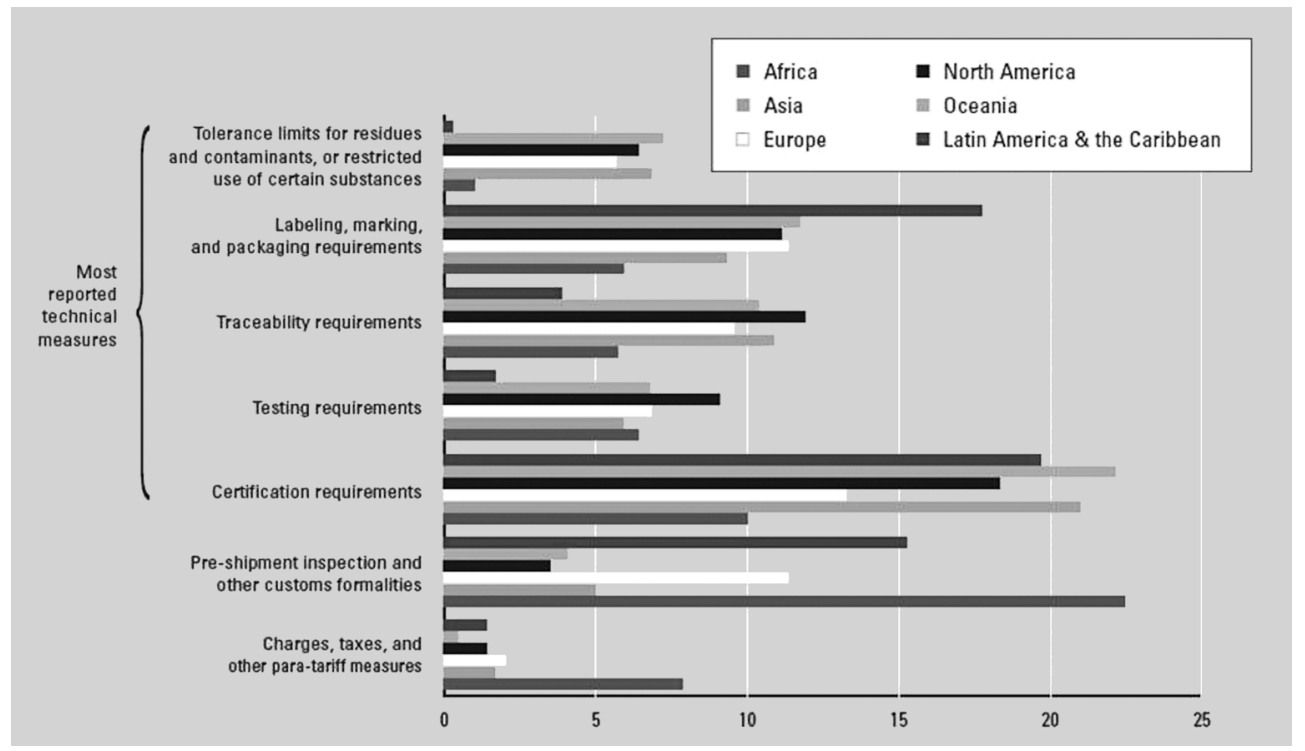

Source: Mimouni et al. (2009), figure 1 in section 1.6.

${ }^{8}$ This is a summary of Mimouni et al. (2009). 
Figure 1, also drawn from their study, explores the possibility that NTM barriers vary across destination by reporting the average share of NTMs across destination for the seven most prevailing type of measure (because firms often reported several measures, per-firm averages were computed in a first step). Certification requirements are important regardless of destination. Not surprisingly, exporters face barriers related to customs formalities in Africa. This is not surprising since tariffs are a more important source of government revenue in that region, but also it is at the customs that rent-seeking activities will endogenously take place in the form of NTMs. In the absence of rent-seeking activities, one might argue that PSI might be warranted, but it is not at all clear that it fulfills its role (see Anson, Cadot and Olarreaga, 2006). So even in this straightforward case, it is not absolutely clear that this NTM is 'actionable', i.e. is welfare-reducing. For exports destined to highincome countries, testing requirements represent an important obstacle for exporters. Two patterns emerge; (i) exporting to countries in the Africa, Latin America and Caribbean regions face more procedural barriers overall; (ii) for at least three countries (Chile, Thailand and Tunisia), barriers to regional destinations are highest; (iii) further results (not reported here) suggest that many of the problems reported by the firms surveyed relate to domestic barriers ranging from weak customs and administrative procedures as well a lack of local facilities and infrastructure.

These patterns are informative, and useful, partly because they confirm some of the patterns emerging from the larger earlier data set where it is apparent that technical regulations represent the most frequent form of NTMs. With a larger sample of countries comparisons to averages will be more meaningful. However, it will always remain a difficult task to interpret the implications of subjective statements. It may also be difficult to match the results from questionnaires administered to companies to the responses by firms.

\section{The Distribution of NTMs and of their Ad-valorem equivalents}

We conclude this paper by examining patterns of NTMs and their average tariff equivalents. We draw on the estimates of Kee et al. (2009) who report the aggregate ad-valorem equivalent of NTMs to see if any patterns emerge when the NTM equivalents are extended to individual NTMs. We also inspect the patterns of AVEs and tariffs across NTMs. 


\section{A. The Distribution of NTMs}

We start with a description of the raw data and the distribution of NTMs at the tariff-line level. According to the TRAINS classification, the NTM dummy used by Kee et al. (2009) includes then 4 types of NTMs at the 1-digit level (3000: Price control measures), 10 types at the 2-digit level (3100: Administrative pricing) and 153 types at the 4-digit, most disaggregated, level (3110: Minimum import prices. (Table A1.1 in Annex 1 gives an exhaustive list detailing the NTMs according to these codes). ${ }^{9}$ Kee et al. sample covers NTM's AVE estimates for 91 countries (including $21 \mathrm{HI}-\mathrm{OECD}$ countries) and 4,961 HS-6 product categories (see Kee et

Table 3. Frequency Distribution of the number NTBs per HS-6 product categories (HS-6 products for 93 countries, over 2002-04)

\begin{tabular}{|c|c|c|c|c|c|c|c|c|c|c|c|}
\hline 1-digits & Freq. & Percent & Cum. 2 & 2-digits & Freq. & Percent & Cum. & 4-digits & Freq. & Percent & Cum. \\
\hline 1 & 91,995 & 73.76 & 73.76 & 1 & 84,116 & 67.44 & 67.44 & 1 & 49,176 & 39.43 & 39.43 \\
\hline 2 & 31,151 & 24.98 & 98.74 & 2 & 32,140 & 25.77 & 93.21 & 2 & 33,418 & 26.79 & 66.22 \\
\hline 3 & 1,562 & 1.25 & 99.99 & 3 & 7,909 & 6.34 & 99.55 & 3 & 20,801 & 16.68 & 82.9 \\
\hline \multirow[t]{12}{*}{4} & 15 & 0.01 & 100 & 4 & 538 & 0.43 & 99.98 & 4 & 7,331 & 5.88 & 88.78 \\
\hline & & & & 5 & 20 & 0.02 & 100 & 5 & 4,152 & 3.33 & 92.11 \\
\hline & & & & & & & & 6 & 4,845 & 3.88 & 95.99 \\
\hline & & & & & & & & 7 & 2,190 & 1.76 & 97.75 \\
\hline & & & & & & & & 8 & 1,288 & 1.03 & 98.78 \\
\hline & & & & & & & & 9 & 810 & 0.65 & 99.43 \\
\hline & & & & & & & & 10 & 291 & 0.23 & 99.66 \\
\hline & & & & & & & & 11 & 41 & 0.03 & 99.7 \\
\hline & & & & & & & & 12 & 196 & 0.16 & 99.85 \\
\hline & & & & & & & & 13 & 146 & 0.12 & 99.97 \\
\hline & & & & & & & & 14 & 35 & 0.03 & 100 \\
\hline & & & & & & & & 15 & 3 & 0 & 100 \\
\hline Total & 124,723 & 100 & & & 124,723 & 100 & & & 124,723 & 100 & \\
\hline
\end{tabular}

Each row gives the number of lines with NTBs at the defined level (for example at the 2-digit level, $6.34 \%$ of HS-6 tariff lines have 3 NTBs).

Notes: NTB Digits classification corresponds to the use of digits in the NTB data classification. See Table 2 for definition of 2-digit codes and Figure 2 for definition of 4-digit NTB codes. Following is an example of the level of detail at 1, 2 and 4 digit level for the category Price and control measures:

1-digit: 3000 Price control measures

2-digit: 3100 Administrative pricing

4-digit: 3110 Minimum import prices

Source: authors' computations based on Kee et al. (2009) and TRAINS-WITS data.

${ }^{9}$ For comparison purposes, the new database under construction in the joint ITC-UNCTAD project should give measures for 240 NTMs for 50 countries (of which 20 would be high-income OECD countries) by 2011. 
al.'s Table 3 for the list of countries and their corresponding average AVE of core NTB, pages 188-189).

Following the TRAINS-WITS classification of NTMs, we start with a description of the distribution of these NTMs across HS- 6 tariff lines over the sample of 93 countries used by Kee et al. (2009). This distribution of NTMs is given in table 3. Column 1 give the frequency distribution when NTBs are defined at the 1-digit NTM code level which corresponds to the 'core' definition of the NTB variable used by Kee et al. when they estimate equation (3).

At the 1-digit NTM classification level, the NTM dummy variable recorded at the HS- 6 tariff line level then takes the value 1 when a given country imposes on good $k$ at least one of the four following NTMs:

- Prices control measures (TRAINS code 3100, 3200 and 3300);

- Quantity restrictions (TRAINS code 6100, 6200 and 6300);

- Monopolistic measures (TRAINS code 7100, 7200 and 7900);

- Technical regulations (TRAINS code 8100)

Table 3 shows that $74 \%$ of the HS- 6 tariff lines only have one 'core' NTM and $25 \%$ of the lines have two NTMs. Moving to a more disaggregated level, the percentage of tariff lines with only one NTM falls, but not by much and at the most disaggregated level of NTM definition, 39\% of the tariff lines only have one NTM.

This general lack of multiple NTMs at a disaggregated level justifies extending the global measure of Kee et al. to compute the AVE for each core NTB. Because for $74 \%$ of the AVE estimates (at the country/HS6 product level), there is only one underlying NTB at the 1-digit level (and then, for 26\%, the AVE estimates includes the combined impact of at least 2 NTBs) ${ }^{10}$ then by merging the initial NTBs file from TRAINS-WITS (containing information on the different types of NTBs as described in Table A1.1) with Kee et al.'s AVE database, ${ }^{11}$ we can isolate AVEs for each type of NTMs, for at least $74 \%$ of cases. ${ }^{12}$

This said, to come up with a "classification" of the AVEs of different types of

\footnotetext{
${ }^{10}$ We thank the authors for giving us access to their database.

${ }^{11}$ Available at http://econ.worldbank.org/WBSITE/EXTERNAL/EXTDEC/EXTRESEARCH/0, content MDK:21085342 pagePK:64 214825 piPK:64214943 theSitePK:469382,00.html

${ }^{12}$ For instance, in Kee et al.'s (2009) sample, estimates for the Brazil evidence an NTBs's AVE of 1.08 for the HS6 products " 320810 " and of 1.02 for the product " 821192 ". The TRAINS-WITS database indicates the presence of a NTB of type 6300 (Prohibitions) imposes by the Brazil on product "320810", of type 8100 (Technical regulations) on product " 821192 ". We therefore attribute the Kee at al.'s AVE estimates to the corresponding NTB. However, in the case for instance of product "291249", 3 NTBs are imposed by the Brazil (6100, 6300 and 8100). Then, the corresponding AVE of 1.74 can not be decomposed in this case into each components of the "core" NTB dummy.
} 
NTMs one would need to have simultaneously different types of NTMs for a given product line for the same importing country. This is not possible now, but might be possible with the new data base under construction. Then one could rerun the estimation of Kee et al. (2009) using dummies for each NTM and then one could compare the resulting estimated AVEs for a given country/product. With the data currently available, this can only be done for $26 \%$ of the data where more than one NTM is included.

Pending new data, one can exploit the cross-country dimension of the subsample of the $70 \%$ of observations where the estimated AVE can be linked to the corresponding NTB. Actually, as reported in Figure 2, for a given product (defined at the HS6 level), all countries do not impose the same 2-digit NTB. Indeed, over the 4,961 HS-6 product lines, $60 \%$ face 3 different 2-digit NTMs across the panel and $32 \% 4$ NTMs. Hence, there is some heterogeneity across countries at the HS-6 level which allows us to look for different patterns of restrictiveness across NTMs at the product level. ${ }^{13}$

Figure 2. Distribution over the 93 countries of the number of different 2-digit NTB on a HS6 product lines

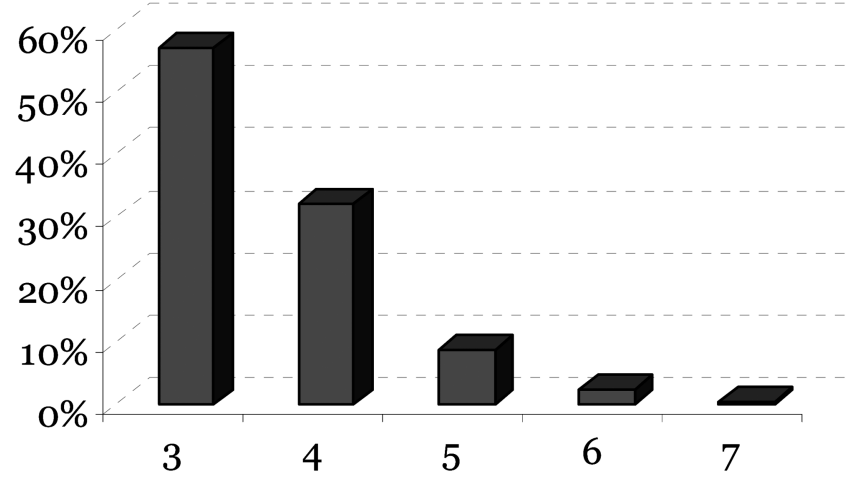

Note: computation on the 84,116 observations having only one type of NTB 2-digits per lines, see Table 2. Source: authors' computations based on Kee et al. (2009) and TRAINS-WITS data.

\footnotetext{
${ }^{13}$ This search should be prefaced by two caveats. First, the NTMs include two data bases, TRAIN-WITS and the EU standard Database which does not report information on the underlying "core" NTMs. Hence we cannot decompose the AVE according to the classification reported in Table A1.1. While this represents only $0.06 \%$ of the AVE estimates reported in the Kee et al.'s database for non-EU countries but, since $90 \%$ of the information from that data base concerns NTMs imposed by the EU, we can only are enable to analyze the underlying NTBs of the $38 \%$ of the AVE computed for the EU. Hence, interpretation concerning EU's NTB is limited. Second, estimates are for the years 2002-2004 with data on "core" NTBs for 1999-2001 depending on the country (see their Table 1 page 184-185 for the year per country in the database).
} 
Table 4. Frequency Distribution of single-NTM AVEs (HS-6 products, 93 countries, for 2002-04)

\begin{tabular}{|c|c|c|c|c|c|c|c|c|c|c|}
\hline \multirow{3}{*}{$\begin{array}{c}\text { 2-digits } \\
3100\end{array}$} & \multirow{3}{*}{$\begin{array}{l}\text { Freq. } \\
(1) \\
50\end{array}$} & \multirow{3}{*}{$\begin{array}{c}\text { Percent } \\
(2) \\
0.06 \%\end{array}$} & \multicolumn{4}{|c|}{ Unweighted average } & \multicolumn{4}{|c|}{ Import-weighted average } \\
\hline & & & \multicolumn{2}{|c|}{$\begin{array}{l}\text { AVE } \\
(3)\end{array}$} & \multicolumn{2}{|c|}{$\begin{array}{c}\text { Tariff } \\
\text { (4) }\end{array}$} & \multicolumn{2}{|c|}{$\begin{array}{c}\text { AVE } \\
(5)\end{array}$} & \multicolumn{2}{|c|}{$\begin{array}{c}\text { Traiff } \\
\text { (6) }\end{array}$} \\
\hline & & & $36.7 \%$ & 0.59 & $16.9 \%$ & 0.09 & $19.3 \%$ & 0.30 & $14.4 \%$ & 0.06 \\
\hline 3200 & 0 & - & - & & - & & - & & - & \\
\hline 3300 & 9 & $0.01 \%$ & $40.6 \%$ & 0.68 & $76.7 \%$ & 0.74 & $15.8 \%$ & 0.48 & $153.5 \%$ & 0.40 \\
\hline 6100 & 21,255 & $25.27 \%$ & $38.1 \%$ & 0.53 & $10.5 \%$ & 0.20 & $33.9 \%$ & 0.53 & $7.7 \%$ & 0.18 \\
\hline 6200 & 5,972 & $7.10 \%$ & $42.6 \%$ & 0.56 & $4.1 \%$ & 0.04 & $32.2 \%$ & 0.44 & $3.1 \%$ & 0.02 \\
\hline 6300 & 2,320 & $2.76 \%$ & $46.4 \%$ & 0.59 & $8.7 \%$ & 0.12 & $20.8 \%$ & 0.41 & $1.8 \%$ & 0.12 \\
\hline 7100 & 251 & $0.30 \%$ & $39.8 \%$ & 0.59 & $24.6 \%$ & 0.44 & $39.9 \%$ & 0.43 & $15.1 \%$ & 0.18 \\
\hline 7200 & 0 & - & - & & - & & - & & - & \\
\hline 7900 & 0 & - & - & & - & & - & & - & \\
\hline 8100 & 54,259 & $64.50 \%$ & $43.3 \%$ & 0.55 & $15.9 \%$ & 0.19 & $25.6 \%$ & 0.41 & $7.2 \%$ & 0.09 \\
\hline Total & 84,116 & $100 \%$ & & & & & & & & \\
\hline
\end{tabular}

Notes :

- Standard errors in italics next to the corresponding average;

- Lines with Prohibitions (6300) can have some positive imports (and then a weighted average) mostly due to the subcategory 6360 (prohibition on the basis of origin -i.e. an embargo) but also, in some cases, the discrepancy can be explained by the fact that the date of the prohibition does not necessarily fit the period for which import data are available, or the prohibition exists at the HS- 8 digit level and trade data is only available at the HS 6 digit level.

- Computation on the 84,116 observations having only one type of NTB 2-digits per lines, see Table 2. Definition of NTB codes at the 2-digit level:

$\begin{array}{llll}3100 & \text { Administrative pricing } & 6200 & \text { Quotas } \\ 3200 & \text { Voluntary export price restraint } & 6300 & \text { Prohibitions } \\ 3300 & \text { Variable charges } & 7100 & \text { Single channel for imports } \\ 6100 & \text { Non-automatic licensing } & 8100 & \text { Technical regulations }\end{array}$

Source: authors' computations based on Kee et al. (2009) and TRAINS-WITS data.

\section{B. AVE patterns for single-NTM products}

We stick with the 2-digit NTM classification level and restrict the sample to HS6 products with a single NTM (this includes 84,116 observations, see Table 4) so that we can interpret the corresponding AVE without ambiguity. The results are shown in Table 4 for the 8 NTMs applied in our sample.

The most frequently used NTM is "Technical regulation" (8100) followed by "Non-automatic licensing" (6100). Countries do not use "voluntary export price restraints" (3200) and use very exceptionally "variable charges" (3300) and "other 
price control measures". ${ }^{14}$ A more detailed description is provided in Figure 3 which shows that loss of information by aggregation is confined to "non-automatic licensing" (6100) and "technical regulations" (8100).

\section{Three conclusions emerge from inspecting these AVEs at the NTM level}

Figure 3. Decomposition 2-digit NTMs into corresponding 4-digit NTM components (HS6 products, 93 countries, for 2002-04)

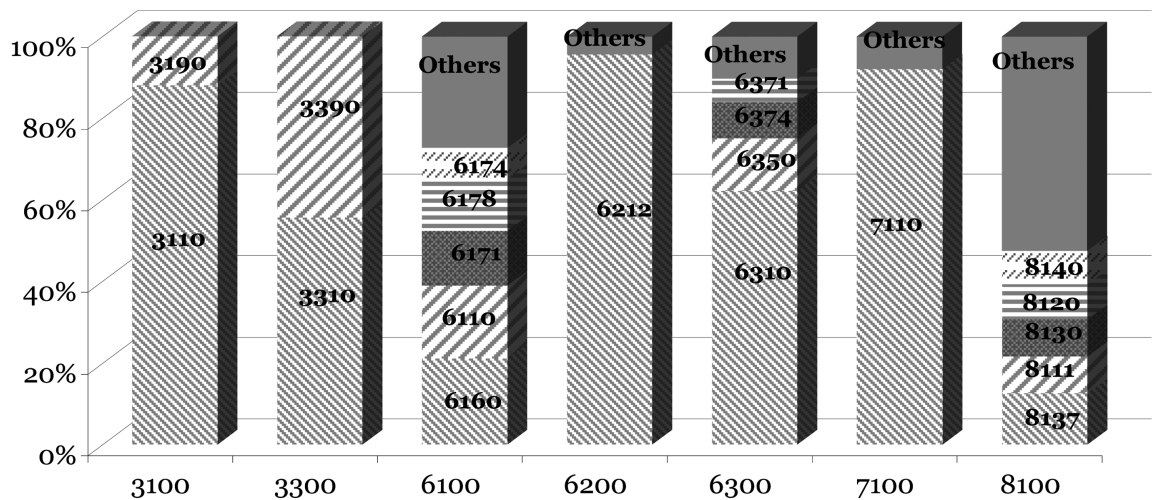

Note:

- Computation on the 84,116 observations having only one type of NTB 2-digits per lines, see Table 2 .

- Definition of corresponding codes:

3110 Minimum import prices

3190 Administrative pricing n.e.s.

3310 Variable levies

3390 Variable charges n.e.s.

6110 Licence with no specific ex-ante criteria

6160 Licence combined with or replaced by special import authorization

6171 Prior authorization to protect human health 81

6174 Prior authorization to protect environment

6178

Prior authorization to ensure national security

6212 Allocated to exporting countries
6310 Total prohibition

6350 Import diversification

6371 Prohibition to protect human health

6374 Prohibition to protect environment

7110 States trading administration

8111 Product characteristics req. to protect human

8120 Marking requirements

8130 Labelling requirements

8137 Labelling requirements to ensure human safety

8140 Packaging requirements

Source: authors' computations based on Kee et al. (2009) and TRAINS-WITS data.

\footnotetext{
${ }^{14}$ This is not surprising since the Uruguay Round agreements generally eliminated all Volontary export restrictions (and the Multi fibre arrangement-related quotas in 2005).
} 
1. The distribution of AVEs is narrow with most NTM having an AVE around $40 \% .{ }^{15}$ This range of estimates at the product-line is narrow and probably underestimates the true variance in estimates. This could be due to our using of all estimates, including those that are not statistically significant. It would be useful to compare ranges when more stringent criteria are imposed on the estimates. Also, next to prohibitions, the highest AVE estimate is for $8100 .{ }^{16}$ Interestingly, this ranking corresponds to the subjective answers obtained from the interviews summarized in section IV.

2. Across all NTMs, the restrictiveness of the measure on import volumes is greater than the corresponding tariff on that product line. Except for variables charges (3300), this holds regardless of the choice of weighing scheme.

3. NTMs are associated with smaller import volumes. This is evident from a

Figure 4. Cumulative Distribution of each NTB 2-digits' AVE (HS6 products, 93 countries, for 2002-04)

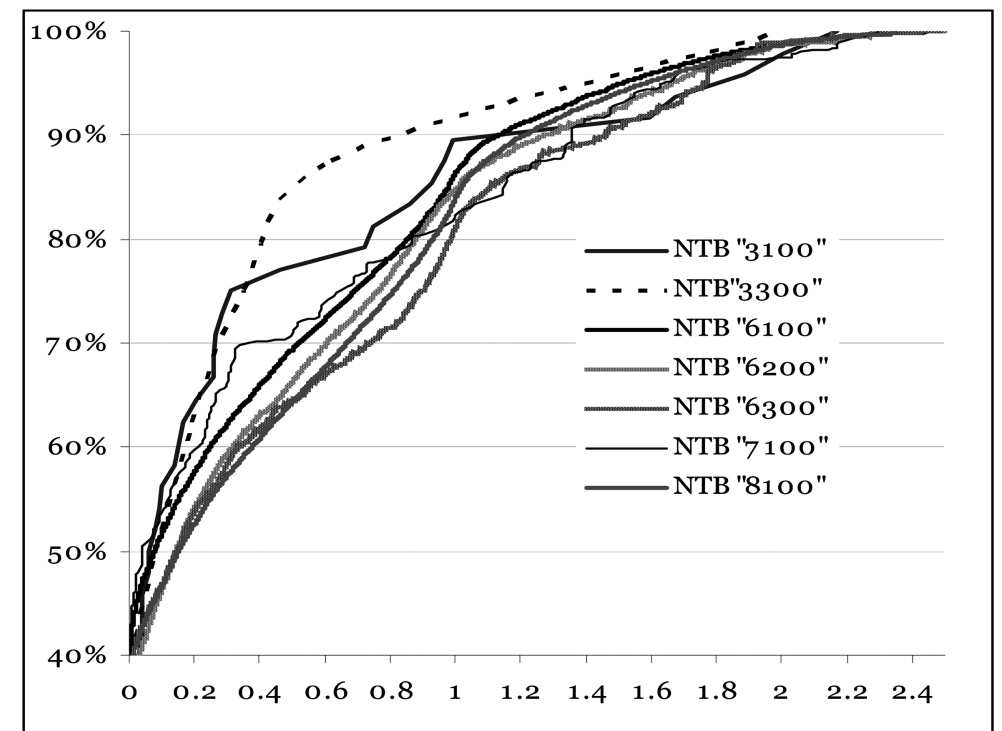

Note: Computation on the 84,116 observations having only one type of NTB 2-digits per lines, see Table 2. Source: authors' computations based on Kee et al. (2009) and TRAINS-WITS data.

\footnotetext{
${ }^{15}$ The corresponding standard errors in italics indicate that the averages are not significantly different from each other.

${ }^{16}$ Note that, as explained by Kee et al. (2009), because of the methodology used to adapt to the zero-one nature of each NTM, the AVE should be interpreted as the marginal contribution of the corresponding NTM after controlling for the tariff level.
} 
Table 5. Frequency and unweighted AVE by 2-digit NTB type by product Section

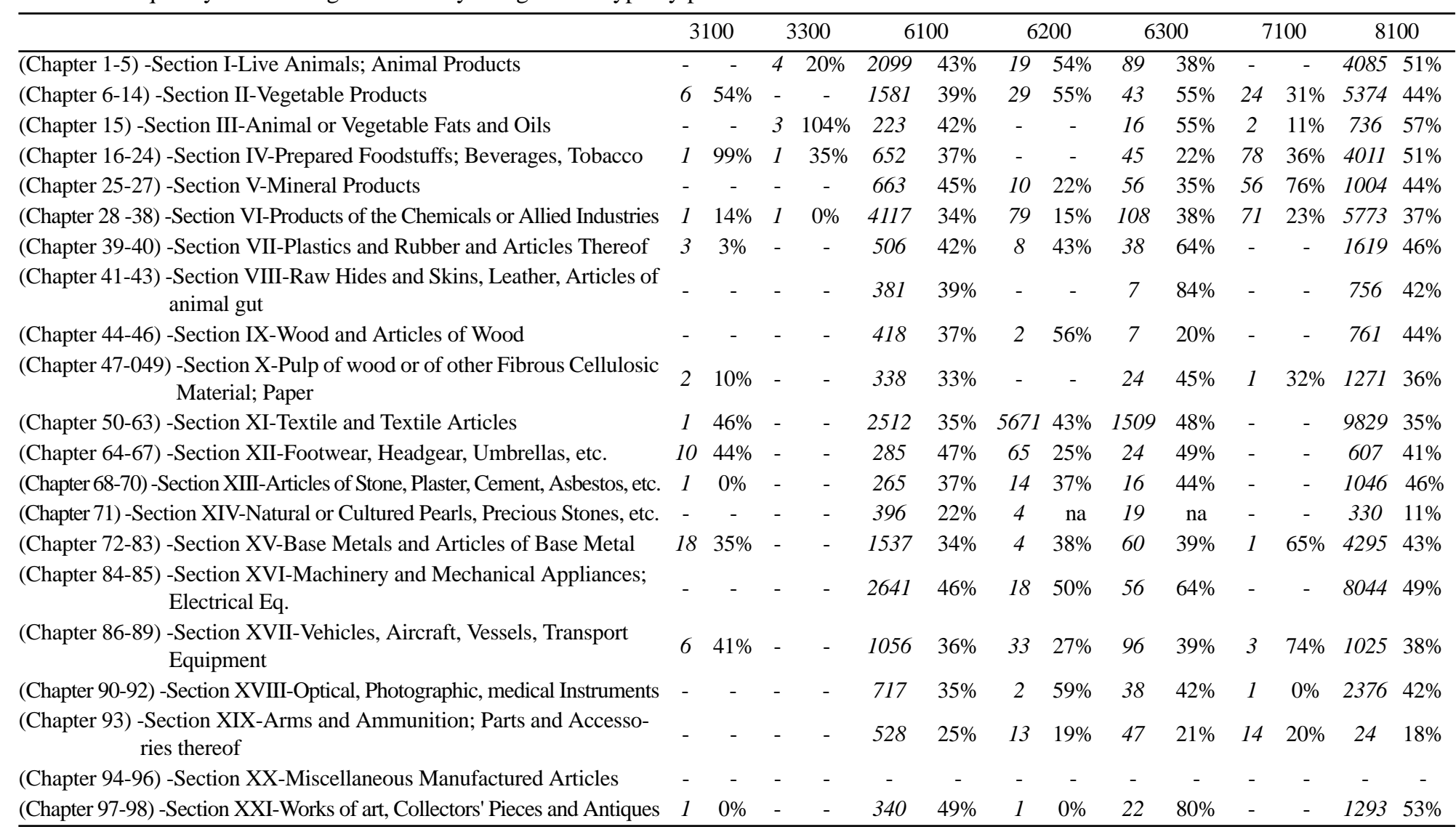

Note: Each cell includes the number of NTBs followed by the corresponding AVE. For example, textiles have 9829 NTBs of type 81 (technical regulation) with an average tariff equivalent (AVE) of $35 \%$.

Source: authors' computations based on Kee et al. (2009) and TRAINS-WITS data. 
comparison of unweighted and import-weighted AVEs. This confirms that imports are endogenous to NTMs and tariffs.

4. The cumulative distribution of AVE estimates (see Figure 4) suggests that two thirds of the AVE estimates at the product line level are in the 25\%-50\% range.

Table 5 disaggregates the distribution of NTBs and corresponding AVEs at the product section level (HS1). Several patterns appear. First, textiles (section 11), a sector that is highly protected world-wide, simultaneously includes the highest number of the 3 types of NTBs: Technical regulation (8100), Quotas (6300) and Prohibitions (6300) with high corresponding AVEs (ranging from $35 \%$ to $48 \%$ ). ${ }^{17}$

Second, the highest count for "Non-automatic licensing measures" (6100) applies for products of the chemicals or allied industries (section 6). This section is

Figures 5. Ad-valorem equivalent of NTMs and per capita income (5a) and NTM count per country (5b)

(Simple average over HS-6 products per country, for 2002-2004)
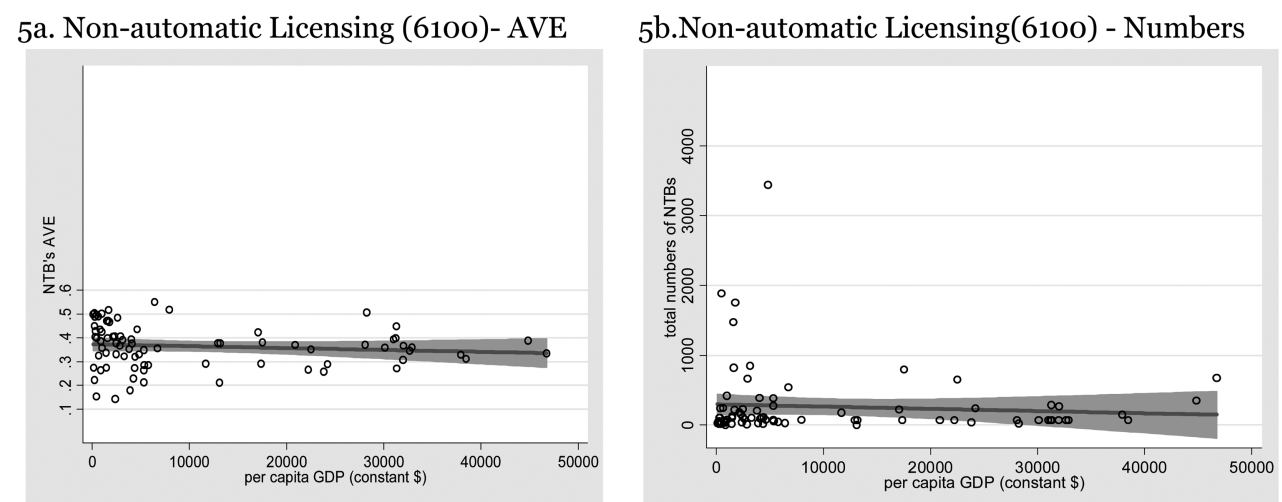

5c. Quotas (6200) - AVE
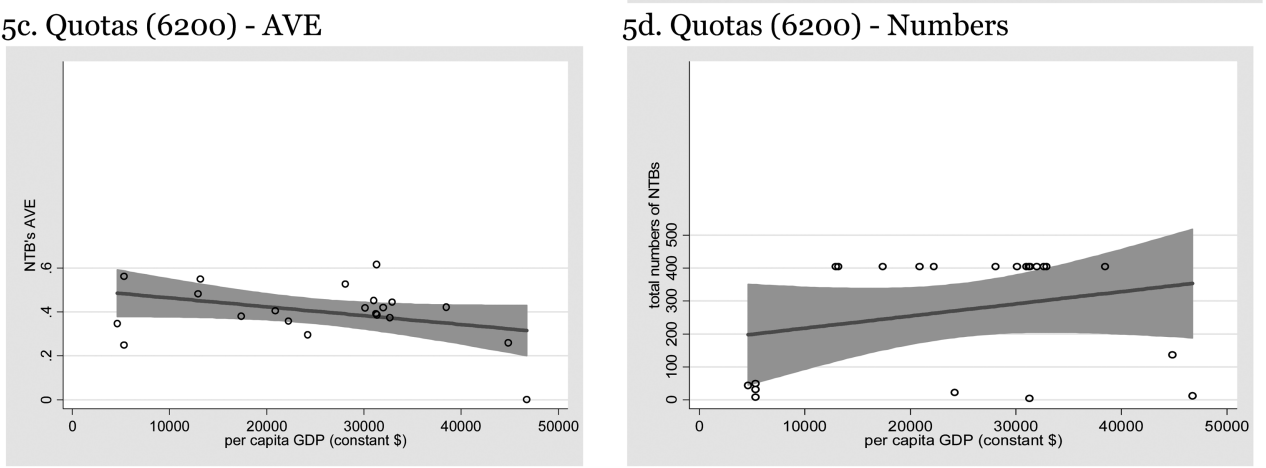

\footnotetext{
${ }^{17}$ The data are for 2002-2004 so they still include quotas measures on textile that have now been abolished.
} 
Figures 5. Ad-valorem equivalent of NTMs and per capita income (continued) (Simple average over HS-6 products per country, for 2002-2004)
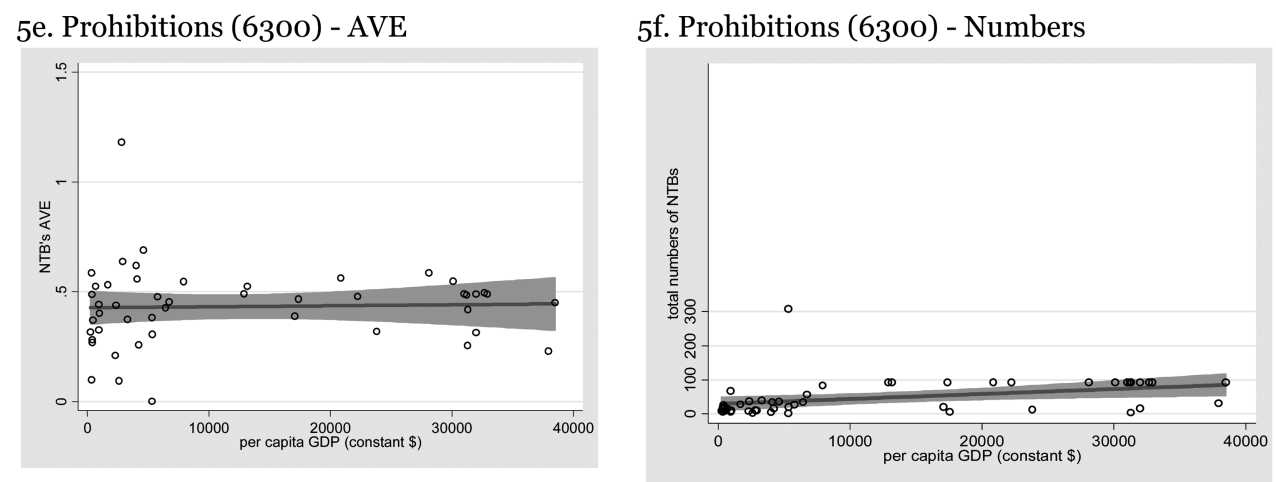

5g. Single Channel for imports (7100) - AVE

5h. Single Channel for imports (7100) Numbers
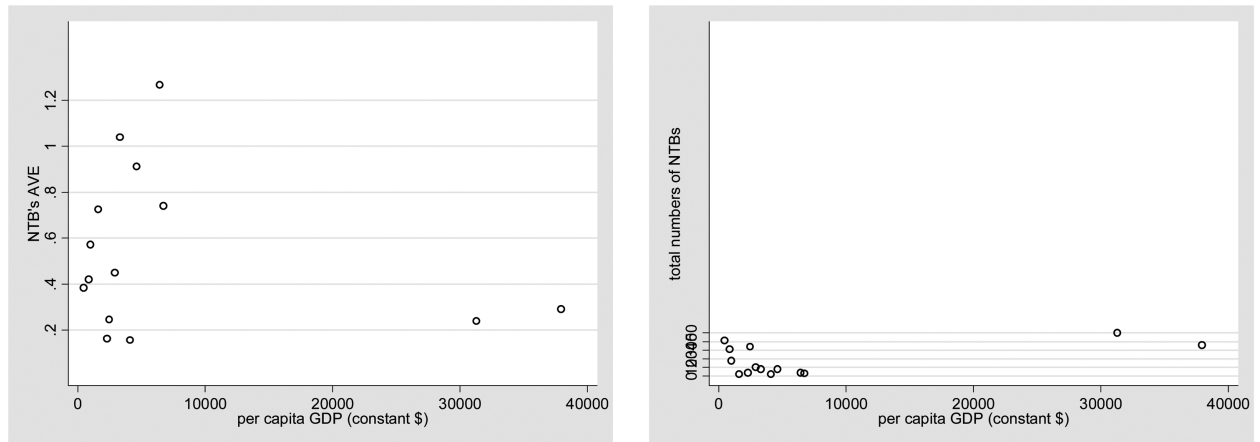

5i. Technical Regulations (8100) - AVE

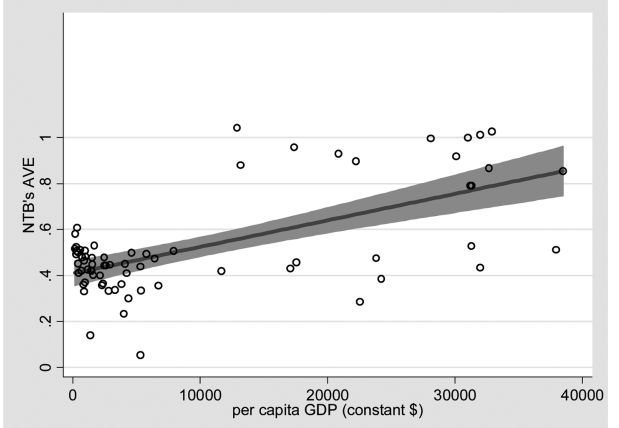

5j. Technical regulations (8100) - Numbers

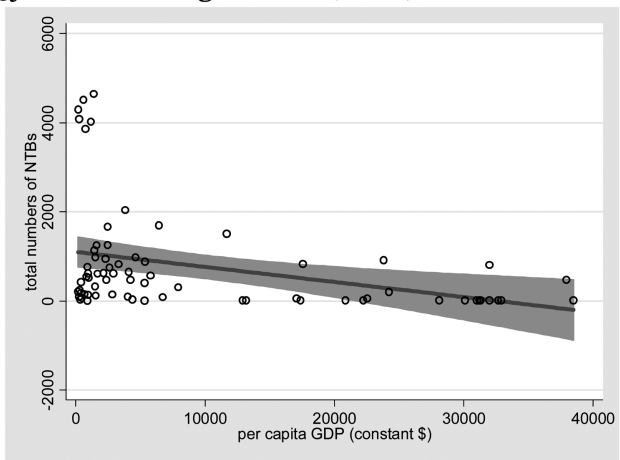

Note: Computation based on 2-digit NTM classification level

lines: fitted values with the corresponding 95\% Confidence Interval (gray area).

Source: authors' computations based on Kee et al. (2009) and TRAINS-WITS data. 
the only one including the 7 types of NTBs on its HS-6 lines.

Third, machinery and mechanical appliances (section 16) face simultaneously some of the highest AVE about (49\%) estimates for "technical regulations" (8100), but also of other NTMs (i.e. for $64 \%$ for prohibitions (6300), and $46 \%$ for nonautomatic-licensing (6100). ${ }^{18}$

Finally, Figure 5 checks for systematic patterns in the estimates of AVEs for each one of the NTMs according to per capita income level (NTM categories 3100 and 3300 are not displayed because of few measures). The figures on the left-hand side (5a) plot the distribution of average AVEs per country (simple average over all HS-6 lines where that measure is applied) and the figures on the right-hand side (5b) plot the count of NTM measures per country. Where it is statistically significant, we report two fitted lines for both measures as a function of per capita GDP.

The following patterns emerge:

1. With the exception of technical regulations (8100), AVE estimates do not show much variation across NTMs. This reflects the combination of the zero-one measurement of NTMs and the common scaling by the import price elasticity at the product line. More precise data on NTMs would introduce greater dispersion in the patterns of AVEs. On the other hand, there is great variation in the number of NTMs per country across NTM classification.

2 Single-channel for imports (7100) is an LDC NTM (with no statistical trend);

3. The pattern for technical regulations (8100) indicates that the restrictiveness of these regulations increases with income per capita. As detailed in Kee et al. (2009, see equation (12) page 12), the AVE is computed from the estimated impact of the NTB on trade divided by the corresponding estimated demand elasticity. Hence, the pattern revealed in Figure 5i can reflect both systematic changes in elasticity estimates across income groups (for example a high import demand elasticity estimate for low-income countries and a lower - in absolute value import demand elasticity estimate for high-income countries) and/or, for a given demand elasticity, more restrictive technical regulations (with a stronger negative impact on trade) in high-income countries. In figure 6 we report the evolution of the import demand elasticity with per capita GDP on the sub-sample of imports facing technical regulation (exactly same sub-sample than Figures $5 \mathrm{i}$ and $5 \mathrm{j}$ ). It seems then that the pattern revealed in Figure 5i actually reflects more trade

\footnotetext{
${ }^{18}$ Since the NTMs are not codified continuously and since the same import elasticity applies to all NTMS, the variations in estimates, which are small, only capture composition effects, i.e. different patterns of NTMs across country-product pairs.
} 
Figure 6. Estimated demand elasticity for imports facing technical regulations (8100) (Simple average over HS-6 products per country, for 2002-2004)

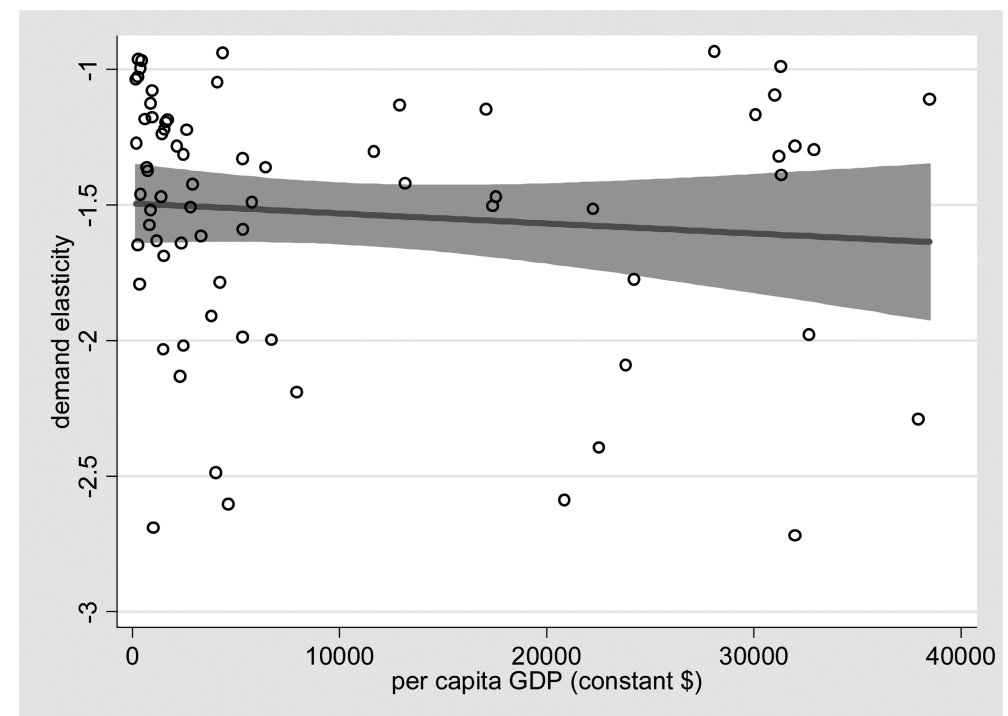

Note: Computation based on the same sub-sample than figures $5 \mathrm{i}$ and $5 \mathrm{j}$.

lines: fitted values with the corresponding 95\% Confidence Interval (gray area).

Source: authors' computations based on Kee et al. (2009) and TRAINS-WITS data.

restrictive technical regulations in high income countries rather than difference in import demand elasticities.

\section{Conclusions}

The combination of case studies with econometric estimates provides a better understanding of the complexity and variety of NTMs and of their restrictiveness on trade. This paper has surveyed the state of understanding prior to the launch of a major joint effort by UNCTAD and ITC to extend systematically the collection of official data along the lines in TRAINS-WITS combined with extensive interviews of exporting companies.

Perceptions gathered through interviews suggest that for developing countries certification requirements are important regardless of destination while customs formalities are perceived as a more important barrier to trade in Africa than in other regions. For exports destined to high-income countries, testing requirements represent an important obstacle for exporters. Not surprisingly, NTMS are also perceived to be particularly costly for agricultural products because of the variety 
of SPS standards across countries and of high costs of compliance costs related to certification. For many low-income countries, barriers to trade are also high at home, notably with respect to certification as the necessary infrastructure to carry out certification is often lacking. Interviews also suggest that arbitrariness and nontransparency plague exporters to developing countries' destination, be it with respect to customs procedures or product standards. Rules of Origin are often perceived as a significant barrier when exports are towards the EU, US or Japan.

The growing number of econometric studies appears to be leading to several stylized patterns. The paper suggests three. First, NTMs are more restrictive than tariffs and low income countries face more restrictive market access conditions. Second, subject to the included controls, NTMs restrict bilateral trade volumes. Third, harmonization of standards increase bilateral trade flows.

Across broadly-defined imports at the section level, NTMs are more restrictive than the corresponding tariffs with two-thirds of the AVE estimates in the 25\%$50 \%$ range. Technical regulations and non-automatic licensing are the most used single-NTM measures and the restrictiveness of technical regulations increases with income per capita.

\section{Acknowledgements}

The authors thank Olivier Cadot, Mona Haddad, Mariem Mallouche, Richard Newfarmer, and Marcelo Olarreaga for comments on an earlier draft.

Received 3 October 2010, Revised 6 January 2011, Accepted 24 January 2011

\section{References}

Anderson J., Bergstrand J., Egger P., and J. Francois. (2008), Non-Tariff Barrier Study Methodology, ECORYS mimeo.

Anderson J. and E. Van Wincoop.(2004), Trade Costs, Journal of Economic Literature, 42, 691-751.

Anson, J. , O. Cadot and M. Olarreaga (2006), Tariff evasion and customs corruption: Does pre-shipment inspection help?, Contributions to Economic Analysis and Policy, $\mathbf{5}(1,33)$.

Blind, K. and A. Jungmittag. (2005), Trade and the Impact of Innovations and Standards: The Case of Germany and the US, Applied economics, 37, 1385-1398.

Carrère, C. and J. de Melo (2011), Non-Tariff Barriers: What Do We Know? What Should 
be Done, Journal of Economic Integration, 26(1), 168-195.

Chen, M.X. and A. Mattoo. (2004), Regionalism in Standards: Good or Bad for Trade?, Canadian Journal of Economics, 41(3), August 2008, 838-863.

Czubala W., Shepherd B., and J. Wilson. (2009), Help or Hindrance? The Impact of Harmonized Standards on African Exports, Journal of African economies, March, 135.

Deardorff A. and Stern R. (1997), Measurement of non-tariff barriers, Economic Department Working Papers \# 179, OECD.

Disdier AC, Fontagné L. and M. Mimouni. (2008), The Impact of Regulation on Agricultural Trade : Evidence From the SPS and TBT Agreements, American Agricultural Economics Association, 90(2), 336-350.

Disdier AC and L. Fontagné. (2008), Trade Impact of European Measures on GMOs Condemned by the WTO Panel, CEPII mimeo.

Feenstra R. (2004), Advanced International Trade: Theory and Evidence, Princeton University Pres, Princeton, NJ.

Fontagné L., Mayer T. and S. Zignago, (2005), Trade in the Triad: how easy is the access to large markets?, Canadian Journal of Economics, 38(4), 1401-1430.

Haveman J. D., NairReichert U. and J. G. Thursby (2003), How Effective are Trade Barriers? An Empirical Analysis of Trade Reduction, Diversion and Compression, Review of Economics and Statistics, 85(2), 480-485.

Hoekman B. and A. Nicita. (2008), Trade Policy, Trade Costs and Developing Country Trade, Policy Research Working Paper, N 4797.

Kee, H.L., Nicita, A. and Olarreaga, M. (2008), Import demand elasticities and trade distortions, Review of Economics and Statistics, 90(4), 666-682, 07.

Kee, H. L., Nicita A. and M. Olarreaga (2009), Estimating Trade Restrictiveness Indices, Economic Journal, 119, 172-199.

Leamer, E. (1990), Latin America as a target of trade barriers erected by the major developed countries in 1983, Journal of Development Economics, 32(2), 337-368.

Mantovani A. and M. Vancauteren. (2003), The Harmonization of Technical Barriers to Trade, Innovation and Export Behavior: Theory with an Application to EU data, Mimeo.

Moenius, J. (2004), Information Versus Product Adaptation: The Role of Standards in Trade, International Business and Markets Research Center Working Paper, Northwestern University.

Moenius, J. (2006), Do National Standards Hinder or Promote Trade in Electrical Products?, IEC Centenary Challenge 2006, http://www.iec.ch/academia/papers/moenius.pdf

Mimouni, H., C. Averbeck, and O. Skorobogatova (2009), Obstacles to Trade from the Perspective of the Business Sector: A Cross-country Comparison, chapter 1.6 in The Global Enabling Trade Report, WEF, Geneva.

Otsuki, T., J.S. Wilson, and M. Sewadeh. (2001a), Saving Two in a Billion: A Case Study to Quantify the Trade Effect of European Food Safety Standards in African Exports, Working paper, The World Bank, Washington, D.C. 
Otsuki, Tsunehiro, John S. Wilson, and Mirvat Sewadeh, (2001b), What price precaution? European harmonisation of aflatoxin regulations and African groundnut exports, European Review of Agriculture Economics, 28(3), 263-284.

Portugal-Perez A., Reyes J-D and J. Wilson. (2009), Beyond the Information Tecnology Agreement: Harmonization of Standards and Trade in Electronics, Policy Research Working Paper, $\mathrm{N}^{\circ} 4916$.

Tamini L., Ghazalian P., Gervais J-P and B. Larue. (2007), Domestic Support and Tariff Reductions in the Presence of non-tariff Barriers: A Gravity Model for Primary and Processed Agricultural Products, MPRA Paper N 2743.

Shepherd B. and J.S. Wilson. (2008), Trade Facilitation in ASEAN Member Countries: Measuring Progress and Assessing Priorities, WB Policy Research Working Paper 4615.

Swann, P., Temple P. and M. Shurmer. (1996), Standards and Trade Performance: The UK Experience, The Economic Journal, 106(438), 1297-1313.

World Bank (2008), A Survey of Non-Tariff Measures in the East Asia and Pacific Region: Policy Research Report, World Bank.

\section{Appendix}

Annex 1. UNCTAD trains Coding System of NTMs included in the Kee et al. (2009)'s sample

Table A1. 1. TRAINS Classification for NTBs included in the Kee et al.(2009)'s sample

\begin{tabular}{llll}
\hline 1-digit & 2-digits & 4-digits & NTM description \\
\hline 3000 & & Price control measures \\
& 3100 & Administrative pricing & Minimum import prices \\
& 3110 & Administrative pricing n.e.s. \\
& 3190 & Voluntary export price restraint \\
& 3200 & & Variable charges \\
& 3300 & 3310 & Variable levies \\
& 3320 & Variable components \\
& 3330 & Compensatory elements \\
& 3340 & Flexible import fees \\
& & 3390 & Variable charges n.e.s. \\
\hline $\mathbf{6 0 0 0}$ & & Quantity control measures \\
& & Non-automatic licensing \\
& 6100 & 6110 & Licence with no specific ex-ante criteria \\
& 6120 & Licence for selected purchasers \\
& 6130 & License for specified use \\
\hline
\end{tabular}


Table A1. 1. TRAINS Classification for NTBs included in the Kee et al.(2009)'s sample (continued)

\begin{tabular}{|c|c|c|c|}
\hline 1-digit & 2-digits & 4-digits & NTM description \\
\hline & \multirow{42}{*}{6200} & 6131 & Linked with export trade \\
\hline & & 6132 & For purposes other than exports \\
\hline & & 6140 & Licence linked with local production \\
\hline & & 6143 & Purchase of local goods \\
\hline & & 6142 & Local content requirement \\
\hline & & 6143 & Barter or counter trade \\
\hline & & 6150 & Licence linked with non-official foreign exchange \\
\hline & & 6151 & External foreign exchange \\
\hline & & 6152 & Importers' own foreign exchange \\
\hline & & 6160 & $\begin{array}{l}\text { Licence combined with or replaced by special import } \\
\text { authorization }\end{array}$ \\
\hline & & 6170 & Prior authorization for sensitive product categories \\
\hline & & 6171 & Prior authorization to protect human health \\
\hline & & 6172 & Prior authorization to protect animal health and life \\
\hline & & 6173 & Prior authorization to protect plant health \\
\hline & & 6174 & Prior authorization to protect environment \\
\hline & & 6175 & Prior authorization to protect wildlife \\
\hline & & 6176 & Prior authorization to control drug abuse \\
\hline & & 6177 & Prior authorization to ensure human safety \\
\hline & & 6178 & Prior authorization to ensure national security \\
\hline & & 6179 & Prior authorization for purposes n.e.s. \\
\hline & & 6180 & License or political reasons \\
\hline & & 6190 & Non-automatic licensing n.e.s. \\
\hline & & & Quotas \\
\hline & & 6210 & Global quotas \\
\hline & & 6211 & Unallocated \\
\hline & & 6212 & Allocated to exporting countries \\
\hline & & 6220 & Bilateral quotas \\
\hline & & 6230 & Seasonal quotas \\
\hline & & 6240 & Quotas linked with export performance \\
\hline & & 6250 & Quotas linked with purchase of local goods \\
\hline & & 6270 & Quotas for sensitive product categories \\
\hline & & 6271 & Quotas to protect human health \\
\hline & & 6272 & Quotas to protect animal health and life \\
\hline & & 6273 & Quotas to protect plant health \\
\hline & & 6274 & Quotas to protect environment \\
\hline & & 6275 & Quotas to protect wildlife \\
\hline & & 6276 & Quotas to control drug abuse \\
\hline & & 6277 & Quotas to ensure human safety \\
\hline & & 6278 & Quotas to ensure national security \\
\hline & & 6279 & Quotas for purposes n.e.s. \\
\hline & & 6280 & Quotas for political reasons \\
\hline & & 6290 & Quotas n.e.s. \\
\hline
\end{tabular}


Table A1. 1. TRAINS Classification for NTBs included in the Kee et al.(2009)'s sample (continued)

\begin{tabular}{|c|c|c|c|}
\hline 1-digit & 2-digits & 4-digits & NTM description \\
\hline \multirow{37}{*}{7000} & 6300 & & Prohibitions \\
\hline & & 6310 & Total prohibition \\
\hline & & 6320 & Suspension of issuance of licences \\
\hline & & 6330 & Seasonal prohibition \\
\hline & & 6340 & Temporary prohibition \\
\hline & & 6350 & Import div ersification \\
\hline & & 6360 & Prohibition on the basis of origin (embargo) \\
\hline & & 6370 & Prohibition for sensitiv e product categories \\
\hline & & 6371 & Prohibition to protect human health \\
\hline & & 6372 & Prohibition to protect animal health and life \\
\hline & & 6373 & Prohibition to protect plant health \\
\hline & & 6374 & Prohibition to protect env ironment \\
\hline & & 6375 & Prohibition to protect wildlife \\
\hline & & 6376 & Prohibition to control drug abuse \\
\hline & & 6377 & Prohibition to ensure human safety \\
\hline & & 6378 & Prohibition to ensure national security \\
\hline & & 6379 & Prohibition for purposes n.e.s. \\
\hline & & 6380 & Prohibition for political reasons (embargo) \\
\hline & & 6390 & Prohibitions n.e.s. \\
\hline & & & Monopolistic measures \\
\hline & 7100 & & Single channel for imports \\
\hline & & 7110 & States trading administration \\
\hline & & 7120 & Sole importing agency \\
\hline & & 7170 & $\begin{array}{l}\text { Single channel for imports for sensitiv e product cate- } \\
\text { gories }\end{array}$ \\
\hline & & 7171 & Single channel for imports to protect human health \\
\hline & & 7172 & Single channel for imports to protect animal health and life \\
\hline & & 7173 & Single channel for imports to protect plant health \\
\hline & & 7174 & Single channel for imports to protect env ironment \\
\hline & & 7175 & Single channel for imports to protect wildlife \\
\hline & & 7176 & Single channel for imports to control drug abuse \\
\hline & & 7177 & Single channel for imports to ensure human safety \\
\hline & & 7178 & Single channel for imports to ensure national security \\
\hline & & 7179 & Single channel for imports for purposes n.e.s. \\
\hline & 7200 & & Compulsory national services \\
\hline & & 7210 & Compulsory national insurance \\
\hline & & 7220 & Compulsory national transport \\
\hline & 7900 & & Monopolistic measures n.e.s. \\
\hline
\end{tabular}


Table A1. 1. TRAINS Classification for NTBs included in the Kee et al.(2009)'s sample (continued)

\begin{tabular}{|c|c|c|c|}
\hline 1-digit & 2-digits & 4-digits & NTM description \\
\hline \multirow[t]{37}{*}{8000} & & & Technical measures \\
\hline & 8100 & & Technical regulations \\
\hline & & 8110 & Product characteristics requirements \\
\hline & & 8111 & Product characteristics req. to protect human health \\
\hline & & 8112 & Product characteristics req. to protect animal health and life \\
\hline & & 8113 & Product characteristics req. to protect plant health \\
\hline & & 8114 & Product characteristics req. to protect env ironment \\
\hline & & 8115 & Product characteristics req. to protect wildlife \\
\hline & & 8116 & Product characteristics req. to control drug abuse \\
\hline & & 8117 & Product characteristics req. to ensure safety \\
\hline & & 8118 & Product characteristics req. to ensure national security \\
\hline & & 8119 & Product characteristics req. for purposes n.e.s. \\
\hline & & 8120 & Marking requirements \\
\hline & & 8121 & Marking requirements to protect human health \\
\hline & & 8122 & Marking requirements to protect animal health and life \\
\hline & & 8123 & Marking requirements to protect plant health \\
\hline & & 8124 & Marking requirements to protect env ironment \\
\hline & & 8125 & Marking requirements to protect wildlife \\
\hline & & 8126 & Marking requirements to control drug abuse \\
\hline & & 8127 & Marking requirements to ensure human safety \\
\hline & & 8128 & Marking requirements to ensure national security \\
\hline & & 8129 & Marking requirements for purposes n.e.s. \\
\hline & & 8130 & Labelling requirements \\
\hline & & 8131 & Labelling requirements to protect human health \\
\hline & & 8132 & Labelling requirements to protect animal health and life \\
\hline & & 8133 & Labelling requirements to protect plant health \\
\hline & & 8134 & Labelling requirements to protect environment \\
\hline & & 8135 & Labelling requirements to protect wildlife \\
\hline & & 8136 & Labelling requirements to control dug abuse \\
\hline & & 8137 & Labelling requirements to ensure human safety \\
\hline & & 8138 & Labelling requirements to ensure national security \\
\hline & & 8139 & Labelling requirements for purposes n.e.s. \\
\hline & & 8140 & Packaging requirements \\
\hline & & 8141 & Packaging requirements to protect \\
\hline & & 8142 & Packaging requirements to protect \\
\hline & & 8143 & Packaging requirements to protect \\
\hline & & 8144 & Packaging requirements to protect \\
\hline
\end{tabular}


Table A1. 1. TRAINS Classification for NTBs included in the Kee et al.(2009)'s sample (continued)

\begin{tabular}{|c|c|c|c|}
\hline 1-digit & 2-digits & 4-digits & NTM description \\
\hline & & 8145 & Packaging requirements to protect \\
\hline & & 8146 & Packaging requirements to protect \\
\hline & & 8147 & Packaging requirements to protect \\
\hline & & 8148 & Packaging requirements to protect \\
\hline & & 8149 & Packaging requirements to protect \\
\hline & & 8150 & Testing, inspection and quarantine requirements \\
\hline & & 8151 & Testing, inspection etc. req. to protect human health \\
\hline & & 8152 & $\begin{array}{l}\text { Testing, inspection etc. req. to protect animal health and } \\
\text { life }\end{array}$ \\
\hline & & 8153 & Testing, inspection etc. req. to protect plant health \\
\hline & & 8154 & Testing, inspection etc. req. to protect environment \\
\hline & & 8155 & Testing, inspection etc. req. to protect wildlife \\
\hline & & 8156 & Testing, inspection etc. req. to control drug abuse \\
\hline & & 8157 & Testing, inspection etc. req. to ensure human safety \\
\hline & & 8158 & Testing, inspection etc. req. to ensure national security \\
\hline & & 8159 & Testing, inspection etc. req. for purposes n.e.s. \\
\hline & & 8160 & Information requirements \\
\hline & & 8161 & Information requirements to protect human health \\
\hline & & 8162 & $\begin{array}{l}\text { Information requirements to protect animal health and } \\
\text { life }\end{array}$ \\
\hline & & 8163 & Information requirements to protect plant health \\
\hline & & 8164 & Information requirements to protect environment \\
\hline & & 8165 & Information requirements to protect wildlife \\
\hline & & 8166 & Information requirements to control drug abuse \\
\hline & & 8167 & Information requirements ensure human safety \\
\hline & & 8168 & Information requirements to ensure national security \\
\hline & & 8169 & Information requirements for purposes n.e.s. \\
\hline & & 8170 & Requirement relative to transit \\
\hline & & 8180 & Requirement to pass through specified customs \\
\hline & & 8190 & Technical regulations n.e.s. \\
\hline & & 819 & Technical regulations nes. to protect human health \\
\hline & & 819 & $\begin{array}{l}\text { Technical regulations nes. to protect animal health and } \\
\text { life }\end{array}$ \\
\hline & & 819 & Technical regulations nes. to protect plant health \\
\hline & & 819 & Technical regulations nes. to protect environment \\
\hline & & 819 & Technical regulations nes. to protect wildlife \\
\hline & & 819 & Technical regulations nes. to control drug abuse \\
\hline & & 819 & Technical regulations nes. to ensure human safety \\
\hline & & 819 & Technical regulations nes. to ensure national security \\
\hline & & 819 & Technical regulations nes. for purposes n.e.s. \\
\hline
\end{tabular}




\section{Annex 2. Distribution of NTMs over products/sector}

Figure A2. 1. Distribution of each NTB 2-digits' AVE over the HS6 products (unweighted and weighted average on the 93 countries, for 2002-04)
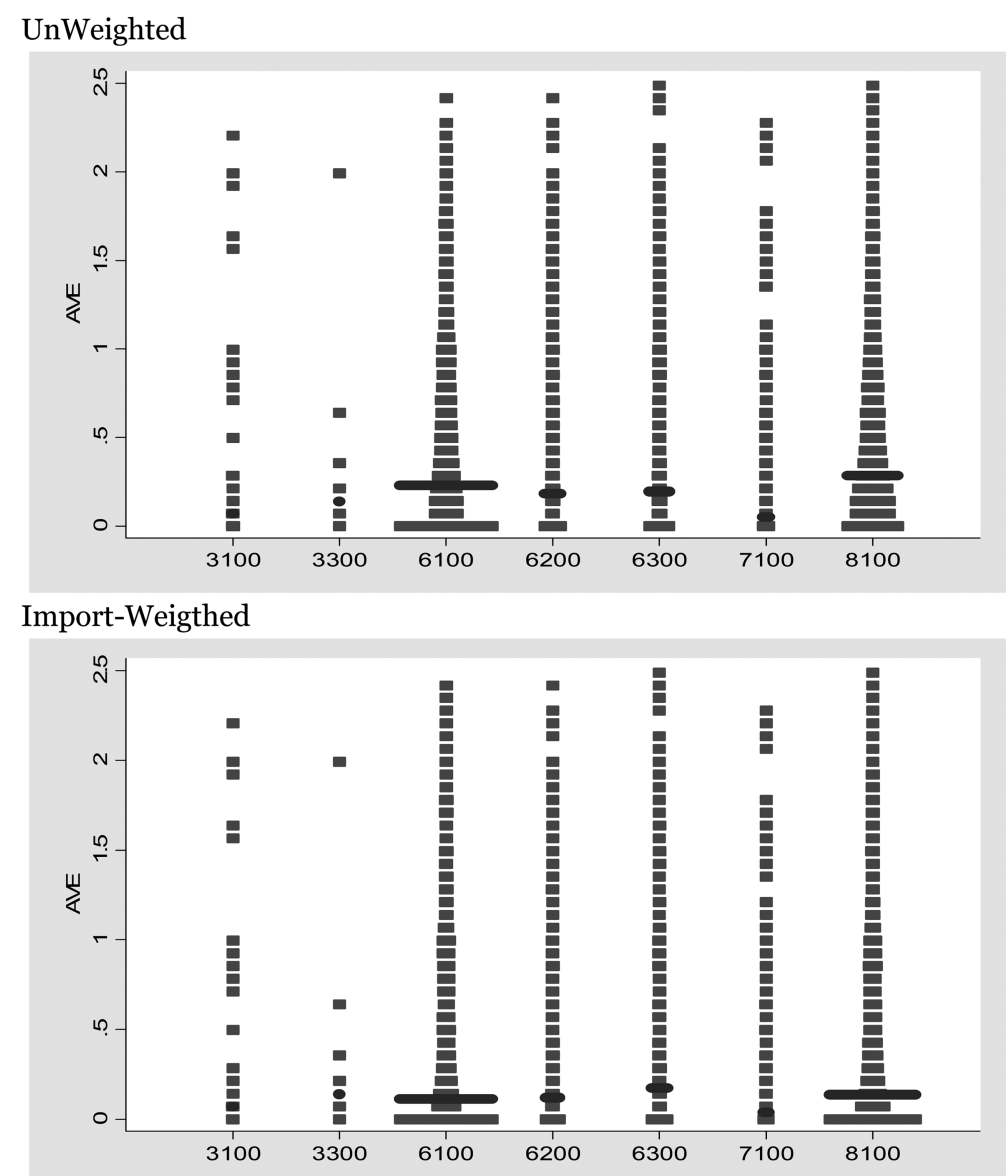

Note: Median AVE in red.

Source: authors' computations based on Kee et al. (2009) and TRAINS-WITS data. 